\title{
Prospects of Integrated Photovoltaic-Fuel Cell Systems in a Hydrogen Economy: A Comprehensive Review
}

DOI:

10.3390/en14206827

\section{Document Version}

Final published version

Link to publication record in Manchester Research Explorer

\section{Citation for published version (APA):}

Ogbonnaya, C., Abeykoon, C., Nasser, A., Turan, A., \& Sunday Ume, C. (2021). Prospects of Integrated Photovoltaic-Fuel Cell Systems in a Hydrogen Economy: A Comprehensive Review. Energies, 14(20), [6827]. https://doi.org/10.3390/en14206827

\section{Published in:}

Energies

\section{Citing this paper}

Please note that where the full-text provided on Manchester Research Explorer is the Author Accepted Manuscript or Proof version this may differ from the final Published version. If citing, it is advised that you check and use the publisher's definitive version.

\section{General rights}

Copyright and moral rights for the publications made accessible in the Research Explorer are retained by the authors and/or other copyright owners and it is a condition of accessing publications that users recognise and abide by the legal requirements associated with these rights.

\section{Takedown policy}

If you believe that this document breaches copyright please refer to the University of Manchester's Takedown Procedures [http://man.ac.uk/04Y6Bo] or contact uml.scholarlycommunications@manchester.ac.uk providing relevant details, so we can investigate your claim.

\section{OPEN ACCESS}




\title{
The application of management accounting practices towards the sustainable development of family businesses: A critical review
}

\author{
Chamila H. Dasanayaka ${ }^{a, *}$, David F. Murphy ${ }^{a}$, Padmi Nagirikandalage ${ }^{\mathrm{b}}$, Chamil Abeykoon ${ }^{\mathrm{c}}$ \\ ${ }^{a}$ Institute of Business, Industry and Leadership, Business School, University of Cumbria, Paternoster Row, Bowerham Rd, Lancaster, LA1 3JD, UK \\ ${ }^{\mathrm{b}}$ Nottingham Business School, Nottingham Trent University, 50 Shakespeare St, Nottingham, NG1 4FQ, UK \\ ${ }^{\mathrm{c}}$ Department of Materials, Faculty of Science and Engineering, The University of Manchester, Oxford Road, M13 9PL, Manchester, UK
}

\section{A R T I C L E I N F O}

\section{Keywords:}

Management accounting practices

Family business

Sustainable development

Economic performance

Environmental performance

Environmental management accounting

Environmental dynamism

\begin{abstract}
A B S T R A C T
The purpose of this study is to comprehensively review the extant literature on the application of management accounting practices (MAPs) to the sustainable development of family businesses (FBs), and to identify future research avenues. Academic interest in the field of MAPs in family businesses as well as the concept of sustainable development has been growing rapidly due to the fast-moving business landscape associated with environmental dynamism, particularly over the past two decades. Consequently, some authors claim that the heterogeneous characteristics of FBs apparently lead to a lower degree of information asymmetry, and that this, in-turn, may weaken the need for MAPs. On the other hand, some studies emphasise that the distinctive conflicts of interest in FBs and some contingent factors (for example, intense competition in the industry) are triggers for the adoption of MAPs by FBs. Given these mixed research outcomes and the absence of a comprehensive study that demonstrates the state-of-the-art in this research stream, this paper aims to review previously reported key works to thoroughly investigate the above mentioned factors with a view to exploring the existing knowledge gap. The holistic conclusion arrived at by the study points to the fact that there seems to have a considerable impact of family involvement on business performance achieved through the application of MAPs. Nonetheless, the impact of certain heterogeneous characteristics of FBs on the application of environmental management accounting (EMA) practices, which is a sub-stream of MAPs, is yet to be explored.
\end{abstract}

\section{Introduction}

Management accounting (MA) is a combination of a number of disciplines such as accounting, finance, and management consisting of numerous leading-edge techniques which are crucial to drive a business successfully (CIMA, 2011). Traditionally, the primary focus of management accounting practices (MAPs) was to determine the cost of products, processes, or projects. The evolution of MAPs demonstrates a constant development to assist businesses to cater to the demands of the rapidly changing external environment (Scapens, 1994; Kaplan, 1998). Consequently, MAPs have currently become multi-disciplinary management tools comprising a chain of practical techniques to generate accurate information which assists businesses to make precise decisions to formulate and implement corporate strategies more effectively and efficiently than ever before (Scapens, 1994; Kaplan, 1998; Chenhall, 2003). Hence, it can be claimed that MAPs play a vigorous part in business management procedures in the modern world.
In the latter part of the 1980s, a momentous approach towards developing the concept of sustainable management accounting as a stem of the mainstream of MAPs was noticed. This was led by global crises such as the oil price shock, increased intensive competition, and the pressure of stakeholders on corporates to be more accountable and transparent in enhancing the quality of life and also to be environmental responsiveness (Abdel-Kader and Luther, 2006; Epstein and Birchard, 1999). Consequently, several empirical studies have evidenced that the application of MAPs could directly and indirectly impact on enhancing corporate performance in economic, social and environmental spheres. For example; Ahmad (2012) pointed out that the information provided by MAPs (both conventional and contemporary practices) have a substantial possibility of uplifting the economic performance of businesses through enhancing the efficacy of managerial performance while continuously reducing wastage and utilising resources more effectively. Moreover, many reported works (Schaltegger and Burritt, 2010; Gunarathne et al., 2020; Abdel-Kader and Luther, 2006) have claimed that

\footnotetext{
* Corresponding author.

E-mail address: chamila.dasanayaka@uni.cumbria.ac.uk (C.H. Dasanayaka).
} 
MAPs and their advanced accounting techniques such as environmental management accounting (EMA) have been used as information generators and also as mediators to provide information for decision making, planning, and control purposes to achieve economic gains while accomplishing socio-environmental goals. Accordingly, a number of researchers (Bennett and James, 1997; Lavia López and Hiebl, 2014) have argued that the application of MAPs is one of the potential ways for any form of business to constantly rejuvenate itself to achieve sustainability goals within a rapidly changing environment. Therefore, MAPs have become one of the promising mechanisms/tools used in the business context for sustainable development.

Considering the extant research outcomes related to MAPs for the sustainable development of different business contexts, the context of family businesses (FBs) has been recognised separately due to the heterogeneous entities involved, and due to family involvement in business operations. Accordingly, several researchers have recognised that the application of MAPs for the sustainable development of FBs has primarily been dependent upon the degree of owner-managers' involvement in business activities (Speckbacher and Wentges, 2012; Feldbauer-Durstmüller et al., 2012; Hiebl et al., 2012, 2013; Senftlechner and Hiebl, 2015), while some studies claim that contingency factors such as internal changes in a business, size/scale, institutional pressure, and intensive competition are some of the key determinants of the application of MAPs in FBs (Feldbauer-Durstmüller et al., 2012; Duréndez et al., 2011; Lavia López and Hiebl, 2014). Moreover, according to the research outcomes on the adoption of environmental management accounting (EMA) and strategies, particularly by small to medium family-owned businesses, external environment pressures have been recognised as a dominant trigger (Halila, 2007; Heras and Arana, 2010; Nawrocka, 2008). However, some recent researchers have claimed that internal resources/capabilities are the most influential triggers, especially due to family involvement in business operations (Graafland, Smid, 2016; Huerta et al., 2017; McKeiver and Gadenne, 2005).

Given these circumstances, inconsistent research outcomes on the application of MAPs and EMA for sustainable development in the FB context raise challenges in arriving at a solid and unified conclusion. Likewise, and more importantly, no comprehensive review work has been carried out so far to identify/analyse the application of MAPs in the sustainable development of FBs, as per the authors' knowledge. Only a few reviews have been carried out to provide a holistic view of accounting practices in FBs (e.g. Salvato and Moores, 2010; Songini et al., 2013; Senftlechner and Hiebl, 2015; Prencipe et al., 2014). However, these works have also not directly addressed the concept of sustainable development or its three pillars. Similarly, sustainable development is a rapidly burgeoning phenomenon with a growing focus on social and environmental issues across the world, while FBs are also rapidly encountering the dynamism of the global environment. Hence, it is imperative to collect an inventory of reported works to date through a systematic literature review to identify areas that are already being developed and the trends that they reveal. This would help to uncover knowledge gaps that could be filled by further development of research in the area. Accordingly, the main purpose of this review is to identify particular knowledge gaps in the current literature by reviewing the extant literature related to three themes (i.e. antecedents, configurations, and outcomes of the application of MAPs for the sustainable development of FBs). However, due to the wide scope of the concept of sustainable development, this review only focuses on two pillars (i.e. economic and environmental) of the three main pillars of sustainable development (i.e. economic, environmental and social performance) in order to perform a critical and in-depth analysis. Three research questions were formulated to address the aims of this study, as follows:

1) What are the motivational drivers and barriers to the adoption of MAPs towards enhancing the economic and environmental performance of FBs?
2) What are the configurations of the application of MAPs towards enhancing the economic and environmental performance of FBs?

3) What are the outcomes of the application of MAPs towards enhancing the economic and environmental performance of FBs?

This paper is structured as follows. Sections 1.1 and 2 discuss the theoretical perspective and the research methodology of the paper, respectively. Thereafter, Section 3 presents the findings and discussion under the thematic analysis. Finally, the conclusions and avenues for future research are presented in section 4, based on the key knowledge/ research gaps identified.

\subsection{Theoretical perspective}

\subsubsection{The impact of absolute family ownership on the sustainable performance of $\mathrm{FBs}$}

When a business is built and maintained on absolute family ownership, the owners become very concerned about their businesses reputation. This is because they, need to ensure business longevity in order to transfer a thriving business legacy to future generations (Campopiano et al., 2014). In such a situation, it is believed that the reputation of both family and business rely upon each other (Campopiano et al., 2014; Dyer and Whetten, 2006; Leotta et al., 2017). Therefore, this category of businesses has demonstrated a significantly high motivation towards achieving socio-environmental performance in order to preserve the goodwill and image of both business and family, and also to transfer a well-reputed, sustainable business to future generations (Dyer and Whetten, 2006; Sharma and Sharma, 2011; Campopiano et al., 2014; Le Breton-Miller and Miller, 2016). However, when the ownership of a business invites outside investors to be a part of its operations, this may create a gap between business goals and family values (e.g. family oriented non-economic goals), mainly due to the possible inclination of new investors towards purely economic goals such as short-term profits (Le Breton-Miller and Miller, 2016). Such a situation may lead to a conflict of interests between principles - principles based on the non-economic goals of the owner's family and the largely economic goals of non-family investors (Anderson and Reeb, 2004). Consequently, this may hinder the level/limit of allocation of resources by FBs for investing in socio-environmental activities. In contrast, Connelly et al. (2010) argue that institutional investors who act as dedicated owners are more likely to form long-term sustainability strategies instead of engaging in short-term profit maximisation. Thus, it can be assumed that the above conditions might also motivate FBs to move towards sustainable performance.

Additionally, businesses with an absolute family ownership can recruit family employees based solely on family interests, regardless of meritocratic considerations (Chrisman et al., 2014; Kidwell et al., 2012). Likewise, these family employees may possess the desire and the autonomy to preserve financial resources within their hands to avoid the possible financial risk of investing in socio-environmental activities (Kim et al., 2016). In such a situation, Neubauer et al. (2012) pointed out that the decisions of these family employees are not usually challenged by family owners due to family ties, kinship, and the large degree of freedom these employees enjoy in managing the business as they see fit. Considering this evidence, there seems to be a significant relationship between the sustainable performance of FBs and the strategic orientation of business owners, whether they are family members or outside investors.

\subsubsection{The impact of family management on the sustainable performance of} FBs

Generally, a greater family involvement in managerial roles in the FB context often reflects a centralised decision-making form of the business. This managerial structure implies a huge impetus of businesses to preserve their reputation, which is primarily led by the high emotional motivation of the owner-manager regarding the reputation of the business (Bingham et al., 2011). As a result, some research studies (Le 
Breton-Miller and Miller, 2016; Sharma and Sharma, 2011) demonstrate a significantly high propensity of FBs towards sustainable performance in the case of a high level of family involvement in managerial tasks. Additionally, a study by De Massis et al. (2014) revealed that the managerial power and willingness of family managers are directly associated with the sustainable performance of FBs. In contrast, when non-family employees are in executive positions, research indicates the existence of short-term financially-oriented business performance, which reflects the self-serving, short-term and rent seeking behaviours of non-family employees (Santos et al., 2016). Moreover, the ineligibility of non-family executives for succession may cause them to prioritize short-term financially-oriented performance, instead of long-term sustainability performance (Bingham et al., 2011; Le Breton-Miller and Miller, 2016).

However, some empirical studies (Kidwell et al., 2012; Singh et al., 2015) have pointed out that having high family involvement in managerial roles may lead to asymmetric family altruism. This behaviour can commonly be seen in FBs when family managers begin to act opportunistically to achieve their or their nuclear family's interests. Similarly, this asymmetric family altruism might lead to intra and/or inter family conflicts, especially when the family tree expands and shares of the business are divided among siblings who have divergent goals (Chirico and Bau, 2014). In such a circumstance, there is a high possibility of emerging disagreements among family managers on how and where resources should be invested (Le Breton-Miller and Miller, 2016). Such conflicting behaviour of management in FBs may also weaken the motivation to pursue sustainable performance in order to preserve the socio-emotional wealth and reputation of the business (Campopiano et al., 2014; Le Breton-Miller and Miller, 2016). Furthermore, the possible enormous power of family employees in corporate management may create a lack of professionalism in decision making, which would eventually lead to lesser availability of resources in FBs to invest in socio-environmental performance (Le Breton-Miller and Miller, 2016). Recent work by Yong et al. (2020) explained that green recruitment and/or training existing management have positively impacted on the alignment of business strategy and also on the diffusion of environmental values throughout the firm.

\subsubsection{How the desire of family businesses to preserve socio-emotional wealth} (SEW) would impact on their sustainable performance

The concept of SEW represents "the nonfinancial aspects of a businesses that meet the family's affective needs' (Berrone et al., 2010; Garengo and Bititci, 2007). Recent literature on the SEW perspective (Garengo and Bititci, 2007) suggests that owners of FBs consider their businesses as an endowment that contributes to the social and emotional well-being of their families. Therefore, according to the behavioural agency theory, owners are reluctant to jeopardize those endowments by neglecting their corporate social responsibility. Hence, some researchers argue that FBs have significant motivation to pursue non-economic goals to satisfy both owner/s and stakeholders (Le Breton-Miller and Miller, 2016). Therefore, when family employees are in executive positions, they might take financially risky decisions to preserve and/or increase their SEW through sustainable performance (Garengo and Bititci, 2007).

Even though the SEW concept has been considered as a pro-social stimulus which enhances the social performance of FBs in the early stages of their development, recent studies have found SEW to be a double-edged sword that can either reveal an FB's bright side or dark side (Cruz et al., 2014; Kidwell et al., 2012; Kim et al., 2016). For example, due to the high level of concern of FBs about their family and business image, they are more likely to commit to real environmentally-responsive activities and less likely to act as greenwashes to gain competitive advantages (Kim et al., 2016). However, the dark side of SEW is that when FBs form non-economic goals to save their SEW, this may result in entrenchment, nepotism, cronyism and exploiting resources of businesses for private benefits (Kidwell et al., 2012). Similarly, Kim et al. (2016) stated that FBs have low levels of motivation for investing in sustainability projects when they are overly concerned about the financial stability necessary to sustain and preserve wealth for transferring to future generations. Hence, based on the literature reviewed, it can be assumed that the sustainable performance of FBs is contingent upon the bright or dark side of the SEW prevalent in them.

\section{Methods}

A systematic review is very useful for researchers to move forward with their studies by identifying the existing gaps in knowledge, since it collates existing reported works and summarises them to reflect the current state-of-the-art in the pertinent mainstream. Hence, a systematic review is considered as a higher level of research evidence amongst other field testimonies and empirical studies (Reay et al., 2009). In order to construct the methodological section of this systematic literature review, the five steps proposed by Tranfield et al. (2003) were followed. They are: (i) research definition, (ii) database selection, (iii) identification of keywords and terms, (iv) selection of compatible articles, and (v) data extraction and evaluation. At first, three research questions were defined as discussed in Section 1. Then a comprehensive online search process commenced using four databases (i.e. Scopus, Web of Science, Science Direct and Emerald Insight). As was discussed by Aboelmaged (2017), academicians and practitioners often make use of journals to find and publish the highest level of research findings. Hence, the current researchers began collecting articles from peer reviewed journals by using the selected keywords. Book chapters, conference papers and other articles were excluded in order to focus only on peer-reviewed articles. The initial assessment of the literature helped to better frame the research by identifying key concepts and search terms and also by defining a time framework. As a result, the initial search was limited to the keywords "Management Accounting" OR "Management control system" AND "family business" OR "family firm" AND "sustainability" AND "economic performance" AND" "environmental performance". Next, the search was refined by selecting a time period, 2000-2020. The purpose of defining a time scale was to acquire a current understanding of the sustainability performance of FBs, since the concept of sustainability is a dynamic one. Also, it was noticed that the outcomes of FB related research have been changing over time, since business contexts have tended to steer towards proactive corporate strategic policies in the face of environmental dynamism.

In the initial search, a total of 416 journal papers were chosen excluding duplicated papers by those four databases. Primarily, three manual screening procedures were undertaken, as follows. First, all the articles were manually checked to determine their relevance to the study. Here, the title, abstract and keywords of the selected articles were matched with the key words defined by this study and its scope. Then, any article with no directly relevance to the key words was removed. Thereafter, only 213 papers that were directly related to the key words of the study were selected. Secondly, after a thorough review of the title, abstract and conclusions, some studies which were not directly related to the core of the study were excluded from the analysis, although some of them were used as supplements in the general discussion and the background literature. Accordingly, 43 papers were selected for a final analysis. However, within the final list of 43 papers, it was found that none of the papers focused on the application of MAPs to the FB context to enhance their environmental responsiveness/performance. Hence, the articles which were removed initially due to the first exclusion criteria, because they focused on SMEs, were reviewed again. According to Jenkins (2004), even though the definitions of FBs and SMEs are different to one another, they seem to have some obvious similarities. For example; the structural configuration of the business models of both FBs and SMEs is quite similar, both types of businesses have a flat organisational structures, operate on trust rather than on codified procedures, few individuals make decisions in both contexts guided by personal interests or emotions rather than through formalised systems, and the businesses have both financial and non-financial objectives. Moreover, according to 
the European Commission (2009), most family-owned businesses are SMEs (i.e., the companies have less than 250 employees and a turnover of less than 50 million euro, or, as an alternative to the turnover criterion, the total assets carry a booked value below 43 million euro).

Accordingly, 26 articles were chosen from the context of SMEs to review the application of MAPs in enhancing environmental performance. Interestingly, 12 articles of these 26 articles had discussed family owned SMEs extensively, and therefore, all 26 articles were added to the final list of papers used for analysis. Accordingly, a total of 61 papers were selected for the final analysis of this study. The exclusion and inclusion criteria and the number of journal papers selected at each stage are presented in detail in Fig. 1 (here, $n$ refers to the number of journal papers). The bibliography of the selected final 69 journals is presented in Appendix 1.

A thematic content analysis tool was employed to critically analyse the findings of the selected papers under the three primary themes discussed in the introduction, namely, antecedents, configurations, and outcomes of the application of MAPs in enhancing the sustainable development of FBs. Finally, this procedure was expected to provide a holistic and succinct picture of the research scope while identifying particular areas where further research should be carried out in the future. The conceptual framework of the study is presented in Fig. 2.

\section{Results and discussion}

As was discussed above, this thematic analysis comprises three major categories, namely, antecedents, configurations and outcomes of the application of MAPs for enhancing the sustainable performance of FBs.

\subsection{Antecedents of the application of MAPs for enhancing the economic performance of FBs}

In this section, antecedents (i.e., drivers, barriers and challengers) of the application of MAPs in the FB context for enhancing their economic performance is discussed.

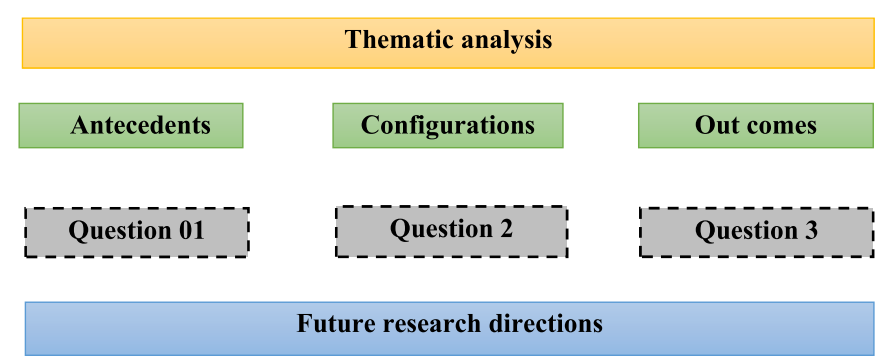

Fig. 2. Conceptual framework of the study.

\subsubsection{The impact of family involvement in corporate governance and management of a business}

Family involvement in corporate governance and management has been recognised as influencing both triggers and barriers to the application of MAPs in FBs, as shown in Table 1. On the one hand, the absence of typical agency costs (i.e. conflicts of interest among owner/s and manager/s) in FBs has resulted in less motivation for the application of formal MAPs in FBs (Speckbacher and Wentges, 2012; Feldbauer-Durstmüller et al., 2012; Moilanen, 2008; Stergiou et al., 2013; Tsamenyi et al., 2008). For example, performance evaluation tools such as the balance scorecard (BSC) has been called a "fancy word" for reporting (Moilanen, 2008, p. 171) since evaluating the performance of managers to reward and to motivate them is not essential due to fewer conflicts of interest among management and ownership of FBs. This is because principals and agents are joined by kinship ties, often, the same person is both the owner and the manager, and the owner has mutual trust in business management. Consequently, formal accounting systems seem to be subservient in special circumstances such as when a person who enjoys the family's trust leads the company, and there is little conflict of interest and information asymmetry.

On the other hand, some authors have identified two types of distinctive agency conflicts in the FB context such as; conflicts of interest between different generations or people in the same family (Schulze et al., 2001); and abusing/diluting the trust of the owner by the management (Stergiou et al. (2013). In such situations, some researchers

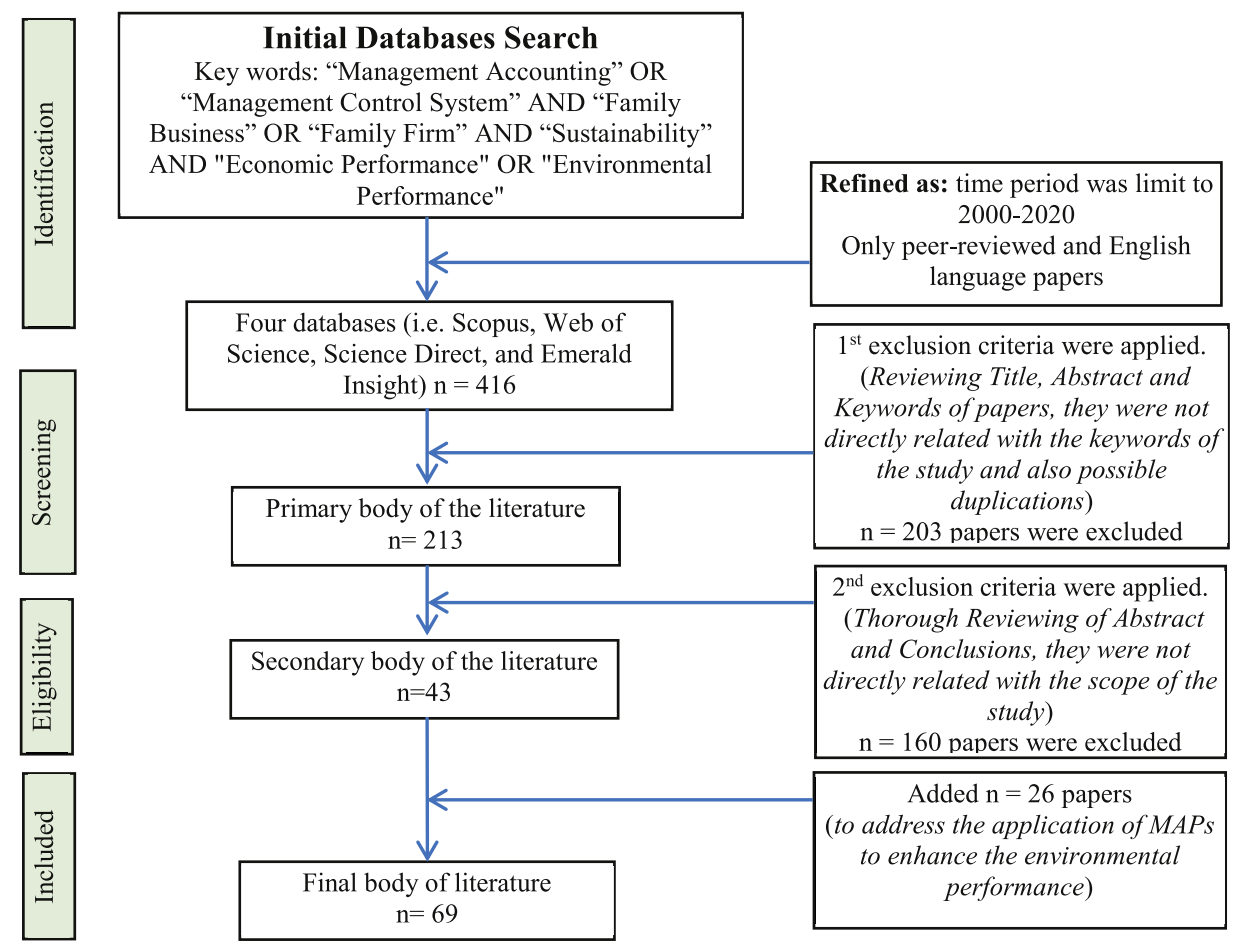

Fig. 1. Procedure used to select peer-reviewed journal articles. 
Table 1

Certain identified factors, which arise due to family involvement, can be considered as triggers or barriers to the adoption of MAPs in FBs.

\begin{tabular}{|c|c|c|}
\hline $\begin{array}{l}\text { Factors that act as triggers } \\
\text { to the application of MAPs }\end{array}$ & $\begin{array}{l}\text { No. Of } \\
\text { papers } \\
\text { cited }\end{array}$ & Reported works \\
\hline Distinctive agency conflicts & 2 & $\begin{array}{l}\text { Schaltegger and Burritt (2010); Stergiou } \\
\text { et al. (2013) }\end{array}$ \\
\hline Business oriented goals & 1 & Leenders and Waarts (2003) \\
\hline $\begin{array}{l}\text { Competent management is } \\
\text { considered as a resource } \\
\text { of the business }\end{array}$ & 2 & $\begin{array}{l}\text { Hiebl et al. (2012) } \\
\text { Moilanen (2008) }\end{array}$ \\
\hline \multicolumn{3}{|c|}{ Factors that act as barriers to the application of MAPs } \\
\hline Fewer typical agency costs & 5 & $\begin{array}{l}\text { Speckbacher and Wentges (2012); } \\
\text { Feldbauer-Durstmüller et al. (2012); } \\
\text { Moilanen (2008): Stergiou et al. (2013), } \\
\text { Tsamenyi et al. (2008) }\end{array}$ \\
\hline $\begin{array}{l}\text { Centralised decision- } \\
\text { making process }\end{array}$ & 4 & $\begin{array}{l}\text { Jorissen et al. (2005); Laitinen (2008); } \\
\text { Kotey (2005). Hiebl et al. (2012) }\end{array}$ \\
\hline Family oriented goals & 6 & $\begin{array}{l}\text { Bloom and Van Reenen (2007); } \\
\text { Imoniana et al. (2011); Leenders and } \\
\text { Waarts (2003); Uddin (2009); Tsamenyi } \\
\text { et al. (2008); Schaltegger and Burritt } \\
\text { (2010) }\end{array}$ \\
\hline
\end{tabular}

have suggested that FBs should invest more in internal control systems which are based on altruism and/or self-control to reduce these distinctive agency costs (Schulze et al., 2001; Stergiou et al., 2013), Moreover, it is quite common that the application of MAPs is often decided based on owners' interests (Uddin, 2009). Also, centralised decision-making processes in FBs may hinder the application of MAPs to their business contexts (Jorissen et al., 2005; Laitinen, 2008; Kotey, 2005). However, businesses often assist management to develop its own professional and personal skills since they consider skilful management as a distinctive resource of their business (Hiebl et al., 2012; Moilanen 2008). This implies that family trust and the bond of the family with management would create more opportunities to reinforce professionalized MAPs in FBs.

Moreover, the distinctive goals of FBs (i.e. family-oriented non-economic goals vs. business-oriented economic goals) have had opposite effect as far as the application of MAPs in FBs is concerned. Six articles shown in Table 1 evidence that higher levels of family-oriented goals, over and above business goals, might lead to the possibility of reducing the need for and the use of MAPs (Bloom and Van Reenen, 2007; Imoniana et al., 2011; Leenders and Waarts, 2003; Uddin, 2009; Tsamenyi et al., 2008; Schaltegger and Burritt, 2010). Conversely, one study stressed that a high level of business-oriented goals, compared with family-oriented goals, would trigger the application of MAPs in FBs (Leenders and Waarts, 2003). Accordingly, it can be assumed that the degree of use of MAPs in FBs might reflect the type of orientation of their business goals.

\subsubsection{The impact of contingency factors on the application of MAPs in FBs}

MAPs have been recognised as a knowledge transferring tool across family generations and between family management and non-family management in the FB context. Hence, in the case of a large internal transformation taking place in a business (for e.g. business succession, business growth to enhance the size/scale of the business, or entering a new market), MAPs may play an important role in managing the increasing complexity of the situation and the environment (Giovannoni et al., 2011). Moreover, a previous study by Youssef (2013) in relating to Egyptian family businesses in textile manufacturing has exemplified that adding new technology to businesses (such as e-commerce) has aided to change their accounting systems via facilitating greater control over inventory and improving planning and budgeting. Besides, other two studies (Mitter and Hiebl, 2017; Moores and Yuen, 2001) have also highlighted that changes to MAPs in FBs might be triggered as firms move through their different stages of life cycle.
Moreover, the size of a business serves as a predictor for the application of MAPs in FBs, since the size of a business decides the nature/ level of complexity and the resource availability of that particular business. Accordingly, several studies, as shown in Table 2, have mentioned that large-scale businesses should have a higher propensity towards the application of MAPs to drive their businesses smoothly, whereas small scale FBs may have less interest in applying MAPs. Furthermore, a comparative study of two Chinese FBs (Tsui-Auch, 2003) has demonstrated that large businesses tend to utilize a professional managerial system to enhance their business performance, whereas small businesses have had to apply such a managerial system particularly to deal with institutional pressure, regardless of the internal capabilities of the business, and its industrial position. Moreover, the study by Chand and Dahiya (2010) argued that MAPs should be applied not only by large businesses but even by SMEs due to the intense competition characterizing the modern business context.

Consequently, it can be concluded that contingent factors such as internal changes in a business, resource availability, institutional pressure and intensive competition in the industry (as shown in Table 2) can be considered as potential factors that act as triggers for the adoption of more professionalized MAPs in a business, whereas the dearth of resources based on the size of the business functions as a barrier. Furthermore, the pandemic has provided an opportunity to businesses to restructure themselves or form ICT-based modern businesses due to the various restrictions on people gathering and working on-site. As a response to this situation, the time has come to restructure businesses, including their visions and missions. In this attempt, management systems such as MAPs would be robust tools with which to conduct such restructuring processes smoothly.

\subsection{The process of implementing MAPs in FBs}

Several articles reviewed in this study have focused on the differences between the use of MAPs by FBs and non-FBs, and their findings were similar. Also, the purpose of application of MAPs by both FBs and nonFBs was to steer their businesses towards sustainability (Becker et al., 2011; Mayr, 2012; Jorissen et al., 2005). Moreover, it was illustrated that

Table 2

Identified contingent factors which act as triggers/barriers to the adoption of MAPs in FBs.

\begin{tabular}{|c|c|c|c|}
\hline \multicolumn{2}{|l|}{ Contingent Factors } & \multirow{2}{*}{$\begin{array}{l}\text { No. Of } \\
\text { papers } \\
\text { cited }\end{array}$} & \multirow[t]{2}{*}{ Reported works } \\
\hline Triggers & Barriers & & \\
\hline $\begin{array}{l}\text { Internal changes } \\
\text { in a business }\end{array}$ & & 1 & Giovannoni et al. (2011), \\
\hline $\begin{array}{l}\text { Introduction of } \\
\text { new technology } \\
\text { to the business }\end{array}$ & & 1 & Youssef (2013) \\
\hline $\begin{array}{l}\text { Different stages of } \\
\text { life cycle }\end{array}$ & & 2 & $\begin{array}{l}\text { Mitter and Hiebl, 2017; Moores } \\
\text { and Yuen, } 2001\end{array}$ \\
\hline $\begin{array}{l}\text { Large scale } \\
\text { businesses }\end{array}$ & & 8 & $\begin{array}{l}\text { Craig and Ken Moores (2005); } \\
\text { Hiebl et al. (2012); Senftlechner } \\
\text { and Hiebl (2015); Singh et al. } \\
\text { (2015); Neubauer et al. (2012); } \\
\text { Giovannoni et al. (2011); } \\
\text { Speckbacher and Wentges } \\
\text { (2012); Feldbauer-Durstmüller } \\
\text { et al. (2012) }\end{array}$ \\
\hline $\begin{array}{l}\text { Institutional } \\
\text { pressure }\end{array}$ & & 1 & Tsui-Auch (2003) \\
\hline \multirow{2}{*}{$\begin{array}{l}\text { Intense } \\
\text { competition }\end{array}$} & & 1 & Chand and Dahiya (2010) \\
\hline & $\begin{array}{l}\text { Small to } \\
\text { medium scale } \\
\text { businesses }\end{array}$ & 5 & $\begin{array}{l}\text { Duréndez et al. (2011); Lavia } \\
\text { López and Hiebl (2014); } \\
\text { Marriott and Marriott (2000), } \\
\text { Neubauer et al. (2012), } \\
\text { García-Pérez-de-Lema and } \\
\text { Duréndez (2007) }\end{array}$ \\
\hline
\end{tabular}


large-scale FBs are more likely to recruit non-family managers to formalise and professionalise their MAPs than small-scale FBs (Feldbauer-Durstmüller et al., 2012; Tsui-Auch, 2003). The following sub-sections present the five key MAPs identified in the FB context during the review process, as shown in Table 3.

\subsubsection{Application of cost accounting techniques by FBs}

According to Huerta et al. (2017), small FBs use traditional costing methods (i.e. standard costing) to calculate their unitary costs. Those businesses have been adding extra costs subjectively using their tacit knowledge when the production process gets more complex. They also use unitary costs to recognise the potential efficacy of individual productions, apart from calculating the profitability of the business (Huerta et al., 2017). A study by Askarany et al. (2009) recognised that large scale businesses are more likely to use more sophisticated MA tools such as $\mathrm{ABC}$ and target costing than small businesses will. Furthermore, it has been evidenced that manufacturing-related small to medium businesses, rather than non-manufacturing businesses, have a significant propensity to adopt sophisticated cost accounting tools due to the complexity of their processes (Askarany et al., 2009). An empirical study by Hopper (1999) found that some Japanese small businesses employ their own costing systems, including standard costing, full absorption costing and marginal costing based on their necessities. According to Ali et al., (2015), the majority of Saudi Arabian based FBs in the oil industry have been applying the $\mathrm{ABC}$ technique to obtain accurate cost information for decision making purposes. This is mainly due to the fact that the oil industry is a highly diverse, highly competitive and a low-cost high-quality strategically-oriented industry. Therefore, these FBs benefit highly from the $\mathrm{ABC}$ tool as it helps them measure and control the production cost precisely to set low prices for their products.

\subsubsection{Application of budgeting and planning techniques by FBs}

In terms of the application of budgeting techniques in the FB context, García-Pérez-de-Lema and Duréndez (2007) identified that small scale FBs have given less importance/priority to planning and cash budgeting techniques, though these are crucial for the future development of their businesses. According to Giovannoni et al. (2011), planning and budgeting processes have been applied by FBs particularly for maximising their financial performance and transferring tacit knowledge to the next

Table 3

Identified key MAPs applied by FBs to enhance their economic performance.

\begin{tabular}{|c|c|c|}
\hline $\begin{array}{l}\text { Identified } \\
\text { management } \\
\text { accounting practice }\end{array}$ & $\begin{array}{l}\text { No. Of } \\
\text { papers } \\
\text { cited }\end{array}$ & Reported works \\
\hline Cost accounting & 4 & $\begin{array}{l}\text { Huerta et al. (2017); Askarany et al. (2009); } \\
\text { Hopper (1999) } \\
\text { Ali et al. (2015) }\end{array}$ \\
\hline $\begin{array}{l}\text { Budgeting and } \\
\text { planning }\end{array}$ & 5 & $\begin{array}{l}\text { García-Pérez-de-Lema and Duréndez } \\
\text { (2007); Giovannoni et al. (2011); Kim et al. } \\
\text { (2016); Ahmad (2012); Chand and Dahiya } \\
\text { (2010) }\end{array}$ \\
\hline $\begin{array}{r}\text { Performance } \\
\text { evaluation } \\
\text { techniques }\end{array}$ & 8 & $\begin{array}{l}\text { Giovannoni et al. (2011): Behery et al. } \\
\text { (2014); Craig and Ken Moores (2005): } \\
\text { Efferin and Hartono (2015); Jorissen et al. } \\
\text { (2005); Speckbacher and Wentges (2012); } \\
\text { Ungerer and Mienie (2018); Thomas and } \\
\text { Anja (2019); Guenther and Heinicke } \\
\text { (2019); Garengo and Bititci (2007); } \\
\text { Audretsch et al. (2013) }\end{array}$ \\
\hline Decision making & 4 & $\begin{array}{l}\text { Chand and Dahiya (2010); Duréndez et al. } \\
\text { (2011): Huerta et al. (2017): Bisogno and } \\
\text { Giovanni (2017) }\end{array}$ \\
\hline $\begin{array}{l}\text { Strategic management } \\
\text { accounting }\end{array}$ & 10 & $\begin{array}{l}\text { Uddin (2009): Németh and Németh (2017); } \\
\text { Chrisman et al. (2005); Becker et al. (2011); } \\
\text { Feldbauer-Durstmüller et al. (2012); } \\
\text { Neubauer et al. (2012); Laitinen (2008); } \\
\text { Speckbacher and Wentges (2012); Guenther } \\
\text { and Heinicke (2019); and Acquaah (2013) }\end{array}$ \\
\hline
\end{tabular}

generation. FBs where the decision-making process has been decentralized and managerial responsibilities are with non-family employees, are more likely to adopt advanced budgeting practices based on the professional skills and guidance provided by employed managers (Kim et al., 2016). Additionally, the extent of use of written budgeting tools is associated with the business size, management structure, business strategies, and perceived environmental uncertainty of a business (Kim et al., 2016). Likewise, some reported works (Ahmad, 2012; Chand and Dahiya, 2010) have recognised budgeting techniques as a system which improves the controlling functions of a business.

\subsubsection{Application of performance evaluation techniques by FBs}

Garengo and Bititci (2007) found that some particular structural configurations of FBs such as, corporate governance structure, advanced information practices, firm's business model and authoritative management style make a significant impact on the application of performance evaluation systems/tools in FBs. Likewise, a study by Audretsch et al. (2013) focused on German family firms in the manufacturing sector reveals that their performance management systems (PMS) are dictated by family monitoring/involvement procedures. Considering performance evaluations tools, study by Giovannoni et al. (2011) explained the benefits of the adoption of the BSC technique by FBs as follows (1). It codifies business strategies and sets of concrete performance measures to be compatible with the business itself. Hence, it is easier to convey the tacit knowledge of a business to other family members and/or to non-family members while the business benefits through evaluating their performance (2). It enables the balancing of both economic (objective) and non-economic (subjective) goals in the same vein. The major drawback identified in the FB context against the application of the BSC tool is that the performance indicators identified by businesses might not be sufficiently aligned with the strategies and goals of those businesses in order to maximise the anticipated outcomes of implementing the BSC tool (Behery et al., 2014). Moreover, Craig and Ken Moores (2005) suggest two feasible options for designing a BSC technique for FBs to measure and evaluate their performance in achieving sustainability: (1). Adding family-specific objectives and distinctive resources (i.e. familiness) to the four indicators of the classical BSC technique (financial, customer, innovation and learning, and internal business processes). For example, introduction of a family-centred goal (such as offering lucrative jobs to family members who wish to work in the family business itself) to the "innovation and learning" indicator, and (2). Adding a fifth indicator to the classical BSC tool which comprises a bundle of all family issues.

However, Efferin and Hartono (2015) argue that these performance measurement indicators and rewarding systems are merely a traditional ritual of FB culture, and that these are carried out simply to reward employees rather than as an objective mechanism to evaluate employees' performance or to achieve business goals. Moreover, Jorissen et al. (2005) also explained that FBs have less use for financial and non-financial performance indicators and rewarding systems for measuring, evaluating and appraising the performance of businesses and employees. According to other reported works (Speckbacher and Wentges, 2012; Thomas and Anja, 2019; Guenther and Heinicke, 2019), the size and age of a business are significant contingent factors when applying multi-perspective performance measurement techniques and incentive contracts for subordinate managers in surveyed businesses. For example, large FBs often use performance evaluation tools like the BSC more when compared to small businesses. These researchers also emphasised that manufacturing and service-related FBs make less use of performance-related payments than sales related businesses. They added that FBs whose major concern is non-financial performance pay less attention to incentive payments. Finally, a recent study by Ungerer and Mienie (2018) presented a conceptual framework termed "Family Business Succession Mapping" (FBSM) that can be adopted as a benchmark to enhance the potential sustainability of FBs across multiple generations. 


\subsubsection{Application of decision-making processes to FBs}

Several previous studies have showed that MAPs may facilitate decision-making processes in small to medium FBs by providing detailed and sophisticated information for better performance (Chand and Dahiya, 2010; Duréndez et al., 2011). According to Huerta et al. (2017), the decision-making processes of FBs are more centralised and depend primarily on family values and expectations. Moreover, Bisogno and Giovanni (2017) revealed how difficult it is for managers to make decisions by overriding family members in many cases due to their centralised power. Therefore, many owners have introduced the enterprises resource planning (ERP) tool to plan the performance of every single unit and then, to make precise decisions in terms of this plan. It was revealed that this type of MA tool may empower managers or other decision-makers to work more freely/independently without disruption from owners/family members. Therefore, owners believe that the application of MAPs have contributed to promoting comprehensive decision support systems. Additionally, the above researchers have conceptualised that the adoption of an ERP tool by small FBs will optimise the performance of managerial, operational, and strategic functions of the businesses. In addition, the implementation of such tools may enhance the quality of strategic analysis mainly by providing financial and non-financial figures and tools for long-term forecasting, industrial analysis, and supply chain analysis (Chand and Dahiya, 2010). On the other hand, adoption of ERP techniques may empower professional shadows and this might disrupt the family trust enjoyed by small FBs (for example, by increasing the agency cost and the impact on non-financial goals).

\subsubsection{Application of strategic management accounting (SMA) in FBs}

A study by Feldbauer-Durstmüller et al. (2012) recognised the importance of making strategic decisions in the FB context when making a big change to a business such as making an investment on another project, launching a new competitive strategy, or expanding the business. According to Uddin (2009), the majority of fast-growing FBs have been following well-designed and advanced strategic procedures to achieve competitive advantages. In the case of a new product market launch, they have been adopting the first mover or early follower strategy. Some comparative studies between family and non-family business have focused on the nexus between strategy and levers of control in family and non-family businesses (for example; Guenther and Heinicke, 2019; and Acquaah, 2013). According to Acquaah (2013), the diagnostic controls on the cost leadership strategy are stronger in the non-FB context whereas interactive controls on the differentiation strategy are stronger in FBs.

Additionally, several other studies have reported that FBs use fewer SMA tools than non-FBs (Becker et al., 2011; Feldbauer-Durstmüller et al., 2012; Neubauer et al., 2012; Németh and Németh, 2017; Laitinen, 2008)). In contrast, studies by Speckbacher and Wentges (2012) and Feldbauer-Durstmüller et al. (2012) confirm that FBs which are managed by employed managers have tended to use SMA instruments, just like non-FBs do. Considering the extant literature, it is clear that SMA research in the FB context has been emerging over the last two decades. This might be due to the fact that SMA has become an imperative accounting tool for any form of business encountering environmental dynamics which arise due to the rapidly changing macro-environment. Chrisman et al. (2005) have highlighted the need for more research on SMA in FBs for the further development of the area based on the knowledge gap and the need of the tool.

\subsection{Outcomes of the application of MAPs in FBs}

Literature has identified that MAPs (whether they are formal or informal) have acted as a mediator by enhancing communication and transferring tacit knowledge/values among employees which would eventually support them to build their trust and confidence in their job roles and performance (Giovannoni et al., 2011; Stergiou et al., 2013).
Similarly, a study by Duréndez et al. (2011) stated that the application of MAPs in small and medium FBs causes an increase in their business performance due to the special ability of MAPs to generate precise information for making timely and relevant decisions. As a result, it can be argued that the application of MAPs would often support businesses to enhance their overall performance while steering them towards success. Besides, Leotta et al. (2017) delineated that in a process of succession, the introduction of a new accounting information system and a cost report would facilitate as an integration system for a smooth transfer of the business into the new generation. Meantime, the findings of their case study have highlighted that the construction of the new generation leadership may emerge as a result of the introduction of new MA practices.

However, Uddin (2009) demonstrated that even when there is a nominal non-family manager employed in a business, the owner's family can still diffuse their controlling power over the business, which may tarnish the efficacy of the application of MAPs. Likewise, Stergiou et al. (2013) claimed that a non-family chief financial officer (CFO) who enjoys the trust placed in him/her by the family could also delay changes and developments in MAPs by abusing the owners' trust in him/her since the behaviour of non-family managers often reflects self-serving, short-term and rent seeking behaviours, as was mentioned by Santos et al. (2016). Additionally, there is some evidence that the application of informal MAPs seems to be a distinctive resource which reinforces the capability of FBs in gaining competitive advantages. This is because a study by Speckbacher and Wentges (2012) mentions that no significant differences in the efficacy of the business process between FBs and non-FBs have been recognised, though most FBs use informal MAPs. Furthermore, these researchers have mentioned that there are no clues that informal MAPs impact on the longevity of FBs. The identified outcomes of the application of MAPs in FBs have been presented in Table 4.

\subsection{Antecedents of the application of environmental management accounting (EMA) in FBs}

Exploring the motivational factors for the adoption of EMA procedures in any form of a business is a key to understanding their choice of environmental management strategies (EMSs) (i.e. reactive, preventive or proactive approaches) along with their implementation processes and performance outcomes. Accordingly, Hillary (2004) has identified two key motivational factors for EMA in small to medium FBs (as external environmental drivers and internal strategic orientation which directly affect the decision to adopt EMA). In the review, two external drivers were identified as shown in Table 5. These are stakeholder pressure and local/regional environmental legislations to control environmental pollution. However, those external pressures have, in general, motivated businesses only towards reactive responses to environmental performance (Ferenhof et al., 2014; Aboelmaged, 2017). Similarly, weak environmental regulations do not exert a huge pressure on businesses to be environmentally responsive (Ahmad, 2012; Voukkali et al., 2017; Mohamed and Jamil, 2020; Chan, 2011).

Table 4

Identified outcomes of the application of MAPs in FBs.

\begin{tabular}{lll}
\hline Identified outcomes & $\begin{array}{l}\text { No. Of } \\
\text { cited } \\
\text { papers }\end{array}$ & Reported work \\
\hline $\begin{array}{l}\text { MAPs work as a mediator in } \\
\text { enhancing the performance of }\end{array}$ & 3 & $\begin{array}{l}\text { Giovannoni et al. (2011); } \\
\text { Stergiou et al. (2013); } \\
\text { FBs }\end{array}$ \\
$\begin{array}{l}\text { Facilitate for succession process and et al. (2011) } \\
\text { construction of the new } \\
\text { generation leadership }\end{array}$ & 1 & $\begin{array}{l}\text { Leotta et al. (2017) } \\
\text { Family involvements tarnish the } \\
\text { efficacy of MAPs }\end{array}$ \\
$\begin{array}{l}\text { Informal MAPs as a distinctive } \\
\text { resource }\end{array}$ & 1 & $\begin{array}{l}\text { Uddin (2009); Stergiou et al. } \\
\text { (2013) }\end{array}$ \\
\hline
\end{tabular}


Table 5

Identified triggers and barriers to the application of EMA in FBs (a summary of the works reported in the literature).

\begin{tabular}{|c|c|c|c|}
\hline \multicolumn{2}{|c|}{ Identified triggering factors } & \multirow{2}{*}{ 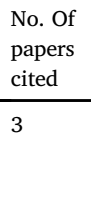 } & \multirow{2}{*}{$\begin{array}{l}\text { Reported works } \\
\text { Halila (2007); Heras and } \\
\text { Arana (2010); } \\
\text { Nawrocka (2008) }\end{array}$} \\
\hline $\begin{array}{l}\text { External } \\
\text { environment }\end{array}$ & Stakeholder pressure & & \\
\hline & $\begin{array}{l}\text { Local and regional } \\
\text { environmental } \\
\text { legislations }\end{array}$ & 7 & $\begin{array}{l}\text { Balzarova and Castka } \\
\text { (2008); Cruz et al. } \\
\text { (2014); Ferenhof et al. } \\
\text { (2014); Heras and Arana } \\
\text { (2010); Le Breton-Miller } \\
\text { and Miller (2016); } \\
\text { McKeiver and Gadenne } \\
\text { (2005); Witjes et al. } \\
\text { (2017) }\end{array}$ \\
\hline \multirow[t]{2}{*}{$\begin{array}{l}\text { Internal } \\
\text { strategic } \\
\text { orientation }\end{array}$} & $\begin{array}{l}\text { Owner-managers' } \\
\text { awareness of } \\
\text { sustainability } \\
\text { performance }\end{array}$ & 3 & $\begin{array}{l}\text { Graafland and Smid } \\
\text { (2016); Hosoda (2018); } \\
\text { McKeiver and Gadenne } \\
\text { (2005) }\end{array}$ \\
\hline & Networking with peers & 5 & $\begin{array}{l}\text { Zobel (2007); Chan } \\
\text { (2011); Granly and } \\
\text { Welo (2014); Halila } \\
\text { (2007); Graafland } \\
\text { (2018) }\end{array}$ \\
\hline \multicolumn{4}{|c|}{ Identified barriers } \\
\hline \multirow[t]{6}{*}{$\begin{array}{l}\text { Internal } \\
\text { organization } \\
\text { barriers }\end{array}$} & Lack of resources & 9 & $\begin{array}{l}\text { Brammer et al. (2012); } \\
\text { Hillary (2004); } \\
\text { McKeiver and Gadenne } \\
\text { (2005); Balzarova and } \\
\text { Castka (2008); } \\
\text { Nawrocka (2008); Chan } \\
\text { (2011); Ferenhof et al. } \\
\text { (2014); Granly and } \\
\text { Welo (2014); Voukkali } \\
\text { et al. (2017) }\end{array}$ \\
\hline & $\begin{array}{l}\text { Lack of employee } \\
\text { engagement due to lack } \\
\text { of knowledge and } \\
\text { sluggish attitudes }\end{array}$ & 8 & $\begin{array}{l}\text { Brammer et al. (2012); } \\
\text { Hillary (2004); } \\
\text { Balzarova and Castka } \\
\text { (2008); Heras and Arana } \\
\text { (2010); Chan (2011); } \\
\text { Granly and Welo (2014); } \\
\text { Alonso-Paulí and Andre } \\
\text { (2015); Voukkali et al. } \\
\text { (2017) }\end{array}$ \\
\hline & Cultural barriers & 4 & $\begin{array}{l}\text { Balzarova and Castka } \\
\text { (2008); Heras and Arana } \\
\text { (2010); Ferenhof et al. } \\
\text { (2014); Voukkali et al. } \\
\text { (2017) }\end{array}$ \\
\hline & $\begin{array}{l}\text { Lack of technical } \\
\text { orientation }\end{array}$ & 4 & $\begin{array}{l}\text { Becker et al. (2011); } \\
\text { McKeiver and Gadenne } \\
\text { (2005); Heras and Arana } \\
\text { (2010); Alonso-Paulí } \\
\text { and Andre (2015) }\end{array}$ \\
\hline & Fewer strategies & 1 & Heras and Arana (2010) \\
\hline & Size of the business & 4 & $\begin{array}{l}\text { Singh et al. (2015); } \\
\text { Aboelmaged (2017); } \\
\text { Lepoutre and Heene } \\
\text { (2006); McKeiver and } \\
\text { Gadenne (2005) }\end{array}$ \\
\hline \multirow[t]{5}{*}{$\begin{array}{l}\text { External } \\
\text { environment } \\
\text { barriers }\end{array}$} & Local barriers & 3 & $\begin{array}{l}\text { Burke and Gaughran } \\
\text { (2006); Hillary (2004); } \\
\text { Chan (2011) }\end{array}$ \\
\hline & Industrial barriers & 3 & $\begin{array}{l}\text { Burke and Gaughran } \\
\text { (2006); Hillary (2004), } \\
\text { Singh et al. (2015) }\end{array}$ \\
\hline & $\begin{array}{l}\text { Weak rules and } \\
\text { regulations }\end{array}$ & 3 & $\begin{array}{l}\text { Voukkali et al. (2017); } \\
\text { Mohamed and Jamil } \\
\text { (2020); Chan (2011) }\end{array}$ \\
\hline & $\begin{array}{l}\text { Lack of support } \\
\text { (government, } \\
\text { consultancy firm) }\end{array}$ & 3 & $\begin{array}{l}\text { Leotta et al. (2017); } \\
\text { Brammer et al. (2012); } \\
\text { Hillary (2004) }\end{array}$ \\
\hline & $\begin{array}{l}\text { High cost of } \\
\text { certification }\end{array}$ & 3 & $\begin{array}{l}\text { Hillary (2004); Alberto } \\
\text { and Erlantz (2019); } \\
\text { Chan (2011) }\end{array}$ \\
\hline
\end{tabular}

In contrast, recent studies have evidenced that EMSs in family owned SMEs have increasingly become formal over time, which is underpinned by their internal resource capabilities to withstand environment dynamism. As a result, increasing awareness of the owner-manager about sustainability values and benefits, enhancing the efficacy of internal operation systems (Groen et al., 2012) have been reported as internal drivers for the adoption of EMSs. Thus, several studies (Ferenhof et al., 2014; Armas-Cruz et al., 2017; Reyes-Rodríguez et al., 2014) have illustrated a paradigm shift in EMS in SMEs from a reactive approach to a proactive environmental responsiveness that helped them gain a wider range of benefits such as; enhanced corporate reputation, better access to the market, lower insurance costs, and the reconciliation of economic benefits with environmental performance. Moreover, some reported studies have recommended that networking with peers is a possible way of enhancing the environmental responsiveness of businesses since this can often offer multiple benefits by increasing employee awareness, ensuring cost efficiencies, sharing resources and competencies and accelerating the implementation processes of EMS (Zorpas, 2010; Chan, 2011; Granly and Welo, 2014; Halila, 2007; Graafland and Smid, 2016).

A detailed review presented by Hillary (2004) split the barriers to the adoption of environmental management by SMEs into two subcategories, namely: internal organisational barriers and external environmental barriers. Accordingly, 11 barriers were recognised by the review, as presented in Table 5. As summarized in Table 5, the dominant external barriers are recognised as high cost of certification, lack of support and guidance from the relevant institutes, weak regulations, industrial barriers, local/regional barriers (e.g. higher waste disposal costs, high raw material costs), less customer requirement, type of industry in which a business is operating, and most importantly, the size of the business. In contrast, an empirical study by Armas-Cruz et al. (2017) found that most businesses operating in the industrial sector have also been neglecting their environmental responsibilities, despite their heavy contribution to pollution. Moreover, SMEs have demonstrated a reactive response to the adoption of EMS (Ferenhof et al., 2014). It has also been reported that SMEs do not use formal and sophisticated tools because they are less affordable, because their business operations are less tech oriented, and due to lack of skills/knowledge (Alonso-Paulí and Andre, 2015). Similarly, Armas-Cruz et al. (2017) stressed that the size of a business is one of the main determinants of the choice of the EM approach (i.e. reactive, compliant, or proactive). Furthermore, medium scale FBs are more likely to adopt a proactive approach to gain competitive advantages, whereas the choice of small businesses is more often a reactive or compliant approach characterized by mere compliance with stakeholders' pressure and legislations (Armas-Cruz et al., 2017). Therefore, it can be claimed that internal organisational barriers, rather than external barriers, are the most significant challenges that FBs encounter in the adoption of EMA.

\subsection{Implementation of environmental management practices in FBs}

A few studies have presented specific environmental management models targeting SMEs to guide them on how to apply environmental management innovation tools to certain aspects of the business, such as how to collaborate with peers, external consultants and EMS support initiatives; and also how to deal with the unique attributes of SMEs such as dearth of resources, both economic and non-economic goals, and centralised decision making (e.g. Burke and Gaughran, 2006; Halila, 2007; Balzarova and Castka, 2008; Witjes et al., 2017). These models offer practical directions/guidelines for SMEs to adopt both formal and informal management control tools productively. During the design stage of this process, an effective collaboration between the management and employees for setting operational objectives is considered as crucial for the successful implementation of EMS (Balzarova and Castka, 2008; Voukkali et al., 2017). However, some empirical studies (Santos et al., 2016; Granly and Welo, 2014) have pointed out that making employees engaged with environmental development processes would be difficult due to certain cultural barriers. In this regard, recent studies by Graafland 
and Smid (2016) and Johnson (2017) have suggested that employees' engagement can be enhanced by developing their skills and knowledge (implementing suitable training programs), by setting performance indicators (this would help employees to identify the duties and responsibilities of their roles) and by implementing a formal, well-designed system of EM (this would assist employees to understand the environmental management strategy of their business).

In contrast, some recent studies (Graafland and Smid, 2016; Jenkins, 2004; Stubblefield Loucks et al., 2010; Lavia López and Hiebl, 2014) have recognised that formal EMS such as ISO 14001 may not be quite suitable for SMEs due to their lack of financial and human resources availability. Hence, those systems need to be downscaled to be aligned with the affordability of SMEs. Meanwhile, there are many other small-scale procedures that SMEs can consider for developing their quality of environmental management without incurring high bureaucratic costs (e.g., informal environmental management strategies). Hence, a study by Graafland and Smid (2016) has stated that the combination of formal and informal management tools seems to be especially feasible for SMEs to enhance their environmental performance. Moreover, SMEs have been applying formal accounting systems such as EMA to enhance the efficacy of their environmental performance while achieving economic benefits, and also to demonstrate reliable information to their stakeholders on how to meet/achieve environmental performance (Nawrocka, 2008). In this attempt, networking is considered to be a feasible instrument that can help with the process of implementation of EMS in SMEs. As Chan (2011) suggests, this is because collaboration with similar businesses and external environmental bodies can minimise uncertainty or ambiguity regarding the implementation of EMS through sharing experience and knowledge, and also, potentially, by sharing certification costs (Halila, 2007; Graafland and Smid, 2016). An earlier study by Halila (2007) discussed possible pros and cons of collaboration with peers. The identified configurations of EMA in FBs have been listed in Table 6.

\subsection{Outcomes of the application of EMA in FBs}

Many studies point out that EMA can derive multidimensional outcomes such as the improved efficacy of internal processes (Groen et al., 2012); economic benefits; enhanced business image; and environmental and social impacts (Ferenhof et al., 2014; Ferreira Rino and Salvador, 2017; Singh et al., 2015). Moreover, Zorpas (2010) explained that EMA can create a robust system that can analyse the production waste of macro and micro SMEs through first forming a set of environmental targets and then helping to create performance indicators tailored to the particular nature of a business. Consequently, this would help managers to make precise decisions regarding their waste management. These outcomes are interdependent and interconnected, and the effectiveness of the outcomes would evolve over time and space with the level of success of the implementation of the EMS process. If the

Table 6

The different types/levels of configurations of EMA identified in FBs.

\begin{tabular}{|c|c|c|}
\hline Implementation of EMA & $\begin{array}{l}\text { No. Of } \\
\text { cited } \\
\text { papers }\end{array}$ & Related literature \\
\hline $\begin{array}{l}\text { Innovative environmental } \\
\text { management strategies }\end{array}$ & 4 & $\begin{array}{l}\text { Burke and Gaughran (2006); } \\
\text { Halila (2007); Balzarova and } \\
\text { Castka (2008); Witjes et al. } \\
\text { (2017) }\end{array}$ \\
\hline $\begin{array}{l}\text { Involving employees to set } \\
\text { operational objectives }\end{array}$ & 2 & $\begin{array}{l}\text { Balzarova and Castka (2008); } \\
\text { Voukkali et al. (2017) }\end{array}$ \\
\hline $\begin{array}{l}\text { Downscaling of some EM tools to } \\
\text { align with the affordability of } \\
\text { SMEs }\end{array}$ & 3 & $\begin{array}{l}\text { Graafland and Smid (2016); } \\
\text { Stubblefield Loucks et al. } \\
\text { (2010); Lavia López and Hiebl } \\
\text { (2014) }\end{array}$ \\
\hline $\begin{array}{l}\text { Combination of formal and } \\
\text { informal management tools that } \\
\text { would be suitable for SMEs }\end{array}$ & 1 & Graafland and Smid (2016) \\
\hline
\end{tabular}

owner/managers' entire purpose of adopting EMS is only to enhance the reputation of their businesses and increase economic benefits, it is questionable to what extent their EMS would work to save the planet, compared with that of an owner whose real purpose in adopting EMS is to save the environment (Heras-Saizarbitoria and Boiral, 2013). This dilemma has been established/analysed by several studies (e.g. Santos et al., 2016; Heras-Saizarbitoria and Boiral, 2013; Jamali, 2010; Castka and Prajogo, 2013).

Some other studies (Ferenhof et al., 2014; Singh et al., 2015a; Ferreira Rino and Salvador, 2017) have recognised a positive impact of the adoption of the ISO 14001 standard on the ecological performance of businesses. A recent study by Graafland (2018) provides a novel view on this debate, as the researcher emphasizes that the adoption of ISO 14001 does not directly cause a significant improvement in the environmental outcomes of SMEs, but that it can be recognised as a mediator that persuades SMEs to improve their ecological performance. This is primarily because SMEs suffer from issues such as a dearth of physical and financial resources, and lack of access to, as well as rather outdated, information/knowledge/technology. Hence, such businesses need guidance/support from external parties to manage their environmental issues. In this case, ISO14001 certification might act as a trigger for SMEs to collaborate with other network partners who can offer guidance and support to develop their ecological procedures (Graafland, 2018). Hence, the point made by Graafland emphasizes that the adoption of the ISO 14001 standard indirectly guides SMEs towards achieving environmental performance. Additionally, according to some studies (Johnson and Schaltegger, 2016; Ferenhof et al., 2014), EMA has been used as a strategic management tool which enables value addition to a business (in both the short and long terms) through improving internal operations and external procedures. However, after carefully considering all these facts, it can be concluded that no clear evidence exists in the extant literature on the impact of family involvement on the outcomes of the application of EMA in FBs. The identified outcomes of the application of EMA in FBs have been presented in Table 7.

\section{Conclusions}

This review attempts to compile a synopsis of the extant research works related to the application of MAPs for the sustainable development of FBs. Due to the sheer breadth of the concept of sustainable development, this paper only focuses on the economic and environmental aspects of sustainable development (two key aspects of the TBL concept). It does not consider the other main pillar of the TBL, which is the social aspect of sustainable development. The aim of this study was to provide a guideline for further research by reviewing the extant literature under three major themes, namely, antecedents, configurations and outcomes. Considering the extant literature and also as was pointed out by Singh

Table 7

Identified outcomes of the application of EMA in FBs.

\begin{tabular}{lll}
\hline Identified outcomes & $\begin{array}{l}\text { No. Of } \\
\text { cited } \\
\text { papers }\end{array}$ & Reported work \\
\hline $\begin{array}{l}\text { Improved efficacy of internal } \\
\text { business processes }\end{array}$ & 1 & Groen et al. (2012) \\
Economic benefits & 1 & $\begin{array}{l}\text { Ferreira Rino and Salvador } \\
\text { (2017) }\end{array}$ \\
Enhanced business image & 2 & $\begin{array}{l}\text { Ferenhof et al. (2014); Singh } \\
\text { et al. (2015) }\end{array}$ \\
$\begin{array}{l}\text { Environmental and social impacts } \\
\text { Greenwashing defeats the real } \\
\text { purpose of sustainable }\end{array}$ & 1 & $\begin{array}{l}\text { Ferenhof et al. (2014) } \\
\text { performance }\end{array}$ \\
$\begin{array}{l}\text { EMS as a mediator for enhancing } \\
\text { eco-performance }\end{array}$ & 1 & $\begin{array}{l}\text { (2013) } \\
\text { EMA as a strategic management } \\
\text { tool }\end{array}$ \\
\hline
\end{tabular}


et al. (2015) in their review, it seems that a few researchers have paid some interest to but have not expended sufficient effort to investigate the impact of MAPs on the sustainable development of FBs. Moreover, the outcomes of these limited number of studies are also contradictory with respect to a number of aspects, particularly the fact that family involvement in business management has been reported to act as both a trigger and a barrier to the adoption of both MAPs and EMA within FBs. Hence, given the nature of the current limited, inconsistent and sometimes contradictory findings, it is recommended that more qualitative and quantitative research be carried out to expand the understanding/knowledge on the subject, and to theorize/generalize the outcomes to pave the way for developing solid, reliable, realistic and homogeneous research findings related to the application of MAPs to sustainable development in FBs.

The holistic view of the extant literature evidences that MAPs in FBs are less relevant due to the latter's informality, flexibility, centralised decision making, lower agency costs, and mutual trust between management and ownership. However, more quantitative research is needed to statistically generalised this finding since this conclusion was based primarily on qualitative studies. Next, the identification of the types of leadership characteristics necessary for institutionalising MAPs in the FB context is an interesting area of study, but only a limited amount of established theoretical knowledge is reported in this area. For example; accountants are considered to be transformational leaders who support management during the process of MA professionalization in FBs. Accordingly, more accounting research integrated with leadership theories would provide a new angle to this topic. Meanwhile, two types of distinctive agency costs of FBs (i.e. conflicts of interest between nonfamily investors and family owners and also between members of different generations) and their impacts on MAPs need to be investigated further.

In the attempt to review the application of specific MAPs (i.e. costing, budgeting, performance evaluation, decision making and strategic management) in FBs, it was realised that, in general, FBs are more likely to apply conventional and informal MAPs, since the businesses are led primarily by the family, who are involved in business management and allocation of resources. However, contingency factors such as intense competition, increased complexity, the large size/scale, strategic choices of a business, and employed management, have been identified as possible triggers for implementing contemporary MAPs in FBs. Moreover, traits of owner managers and other family employees such as generational characteristics, education, and age have had a considerable impact on the choice of MAPs in FBs (i.e. formal/informal or conventional/contemporary). Nevertheless, several studies have reported on the limited amount of research in the last two decades devoted to investigating the impact of MAPs on sustainable performance in FBs. Consequently, there are many areas that are yet to be investigated/explored.

With regard to EMA procedures in FBs, it was identified that no single research study has yet been reported directly focusing on the context of FBs and their heterogeneous characteristics. A few works have been reported covering this research area, but they are categorised under the SMEs research context with a focus on family owned SMEs. Therefore, it is highly recommended that some dedicated research be done on EMA procedures covering all aspects of FBs, particularly considering some of the unique characteristics of FBs (such as absolute ownership, trustworthy management, and family-oriented goals). Based on the existing literature, it was recognised that the adoption of EMA in FBs has been motivated by three forces (i.e. external institutional pressure, internal strategic orientation and networking with peers). However, in order to decide on the most predominant motivational factor among these three factors (or among all other possible factors), more qualitative and quantitative research must be conducted to theorize and generalize the phenomenon. Likewise, in terms of the recognised barriers to the adoption of EMA procedures in FBs, internal organisational barriers seem to be the ones highlighted by previous works, compared to external environmental barriers. More importantly, there was no reported work on different EMA tools or practices/procedures (e.g. environmental cost analysis, environment-related performance indicators, and product life cycle cost analysis) in the FB context, though the impact of family involvement on these practices should be an interesting and fruitful research area.

\section{Declaration of competing interest}

The authors declare that they have no known competing financial interests or personal relationships that could have appeared to influence the work reported in this paper.

\section{List of Abbreviations}

$\begin{array}{ll}\text { ABB } & \text { Activity-Based Budgeting } \\ \text { ABC } & \text { Activity-Based Costing } \\ \text { BSC } & \text { Balance scorecard } \\ \text { EMA } & \text { Environmental Management Accounting } \\ \text { EMAS } & \text { Eco-Management and Audit Scheme } \\ \text { FBs } & \text { Family Businesses } \\ \text { MA } & \text { Management Accounting } \\ \text { MAPs } & \text { Management Accounting Practices } \\ \text { MDGs } & \text { Millennium Development Goals } \\ \text { SD } & \text { Sustainable Development } \\ \text { SDGs } & \text { Sustainable Development Goals } \\ \text { SEM } & \text { Structural Equation Model } \\ \text { SEW } & \text { Socio Emotional Wealth } \\ \text { SMEs } & \text { Small to Medium Enterprises } \\ \text { TBL } & \text { Triple Bottom Line }\end{array}$

Appendix 
Table A1

Bibliography of the selected articles relation to the MAPs of FBs to enhance their economic performance

\begin{tabular}{|c|c|c|c|c|c|}
\hline Authors name & $\begin{array}{l}\text { Published } \\
\text { Year }\end{array}$ & $\begin{array}{l}\text { Research } \\
\text { Destination }\end{array}$ & $\begin{array}{l}\text { Research } \\
\text { method }\end{array}$ & Analytical tools used & Journal published \\
\hline Chan et al. & 2001 & China & Quantitative & Statistics, Regression & The Int. Journal of Accounting \\
\hline Schulze et al. & 2001 & America & Quantitative & $\begin{array}{l}\text { Descriptive statistics, } \\
\text { Regression, Ancova Test }\end{array}$ & Organization Science \\
\hline Moores and Yuen & 20,011 & Australia & Qualitative & Multiple case studies & Accounting, Organizations and Society \\
\hline Upton et al. & 2001 & America & Quantitative & Descriptive satistics & Journal of Small Business Management \\
\hline Tsang & 2002 & Singapore & Quantitative & A comparative case study approach & Journal of Business Venturing \\
\hline Leenders and Waarts & 2003 & Netherlands & Quantitative & Case study approach & European Management Journal \\
\hline Tsui-Auch & 2003 & Singapore-Chinese & Quantitative & A comparative case study approach & Management Learning \\
\hline Craig and Moores & 2005 & Australia & Qualitative & A case study, A conceptual framework & Family business review \\
\hline Jorissen et al. & 2005 & Belgium & Quantitative & $\begin{array}{l}\text { Descriptive statistics, } \\
\mathrm{X}^{2} \text {-test, } U \text { test, Wtest, regression }\end{array}$ & Family Business Review \\
\hline $\begin{array}{l}\text { García-Pérez-de-Lema, } \\
\text { and Duréndez }\end{array}$ & 2007 & Spain & Quantitative & $\begin{array}{l}\text { Descriptive statistics, } \mathrm{X}^{2} \text {-test, ANOVA, Wald } \\
\text { statistics }\end{array}$ & $\begin{array}{l}\text { Int. Journal of Entrepreneurial Behaviour } \\
\text { and Research }\end{array}$ \\
\hline Garengo and Bititci & 2007 & Italy & Quantitative & Descriptive statistics, Regression & $\begin{array}{l}\text { International Journal of Operations and } \\
\text { Production Management }\end{array}$ \\
\hline Bloom and Van Reenen & 2007 & Europe/USA & Quantitative & Descriptive statistics, regression & The Quarterly Journal of Economics \\
\hline Moilanen & 2008 & Finland & Qualitative & A case study & $\begin{array}{l}\text { Qualitative Research in Accounting and } \\
\text { Management }\end{array}$ \\
\hline Tsamenyi et al. & 2008 & Indonesia & Qualitative & A case study & Accounting Forum \\
\hline Laitinen & 2008 & Finland & Quantitative & Descriptive statistics, Regression analysis & $\begin{array}{l}\text { International Journal of Accounting and } \\
\text { Finance }\end{array}$ \\
\hline Chen et al. & 2009 & East Asia & Quantitative & Descriptive statistics, W-test & $\begin{array}{l}\text { Corporate Governance: An International } \\
\text { Review }\end{array}$ \\
\hline Uddin & 2009 & Bangladesh & Qualitative & A case study & Critical Perspectives on Accounting \\
\hline Gulbrandsen & 2009 & Norway & Quantitative & Descriptive statistics, regression & Economic and Industrial Democracy \\
\hline Askarany & 2010 & New Zealand & Quantitative & Pearson's chi-squared test & $\begin{array}{l}\text { International Journal of Production } \\
\text { Economics }\end{array}$ \\
\hline Hatum et al. & 2010 & Argentina & Qualitative & Descriptive statistics & Journal of Change Management \\
\hline Duller & 2010 & Austria & Quantitative & Chi2-test, Fisher test & $\begin{array}{l}\text { Int. Journal of Economic Sciences and } \\
\text { Applied Research }\end{array}$ \\
\hline Duller et al. & 2011 & Austria SFI & Quantitative & $\begin{array}{l}\text { KW-test, Fisher's-Exact-test, } U \text { test, } \\
\text { Jonckheere-Terpstratest }\end{array}$ & $\begin{array}{l}\text { International Journal of Business } \\
\text { Research }\end{array}$ \\
\hline Becker et al. & 2011 & Germany & Quantitative & $U$ test, $\mathrm{W}$-test & Journal of Change Management \\
\hline Giovannoni et al. & 2011 & Italy & Qualitative & Case study & Family Business Review \\
\hline $\begin{array}{l}\text { Speckbacher and } \\
\text { Wentges }\end{array}$ & 2012 & Austria/Germany & Quantitative & Descriptive statistics, Regression & Management Accounting Research \\
\hline Neubauer et al. & 2012 & $\begin{array}{l}\text { Austria/Germany } \\
\text { SFI }\end{array}$ & Quantitative & $\begin{array}{l}\mathrm{X}^{2} \text {-test, Fischer's exact test, KS-test, } \\
U \text { test, Regression }\end{array}$ & European Journal of Management \\
\hline Ghabdian et al. & 2012 & Iran & Quantitative & Descriptive statistics, KS-test, Regression & Int. Journal of Business and Management \\
\hline Mayr & 2012 & Slovakia SFI & Quantitative & $\mathrm{X}^{2}$-test, Fisher's-Exact-test & Int. Journal of Business Research \\
\hline $\begin{array}{l}\text { Feldbauer-Durstmüller } \\
\text { et al. }\end{array}$ & 2012 & Austria SFI & Quantitative & Descriptive statistics, Fisher's-exact-test & $\begin{array}{l}\text { International Journal of Business } \\
\text { Research }\end{array}$ \\
\hline Hiebl et al. & 2012 & Austria SFI & Quantitative & $U$ test & Int. Journal of Business Research \\
\hline Behery et al. & 2013 & $\begin{array}{l}\text { United Arab } \\
\text { Emirates }\end{array}$ & Qualitative & A case study & African journal of business management \\
\hline Youssef. & 2013 & Egyptian & Qualitative & A case study & $\begin{array}{l}\text { Journal of Accounting and Organisational } \\
\text { Change }\end{array}$ \\
\hline Acquaah & 2013 & Ghana & Quantitative & Mediated regression analysis & Journal of Family Business Strategy \\
\hline Audretsch et al. & 2013 & German & Quantitative & Descriptive statistics, Regression & Journal of Family Business Strategy \\
\hline Stergiou et al. & 2013 & Greece & Qualitative & A case study & Critical Perspectives on Accounting \\
\hline Efferin and Hartono & 2015 & Indonesia & Qualitative & A case study & $\begin{array}{l}\text { Journal of Accounting and Organisational } \\
\text { Change }\end{array}$ \\
\hline Bisogno and Giovanni & 2017 & Italy & Qualitative & A case study & African journal of business management \\
\hline Huerta et al. & 2017 & $\begin{array}{l}\text { Mexican and one } \\
\text { American) }\end{array}$ & Qualitative & A multiple-case studies & $\begin{array}{l}\text { Qualitative Research in Accounting and } \\
\text { Management }\end{array}$ \\
\hline Leotta et al. & 2017 & Italy & Qualitative & A case study & $\begin{array}{l}\text { Qualitative Research in Accounting and } \\
\text { Management }\end{array}$ \\
\hline Mitter and Hiebl & 2017 & Austria & Qualitative & Multiple case studies & $\begin{array}{l}\text { Journal of Accounting and Organisational } \\
\text { Change }\end{array}$ \\
\hline Ungerer and Mienie & 2018 & South Africa & Qualitative & A case study & $\begin{array}{l}\text { Int. Journal of Family Business and } \\
\text { Management }\end{array}$ \\
\hline Thomas and Anja & 2019 & German & Quantitative & $\begin{array}{l}\text { Descriptive statistics, Confirmatory factor } \\
\text { analysis }\end{array}$ & Management Accounting Research \\
\hline Guenther and Heinicke, & 2019 & German & Quantitative & $\begin{array}{l}\text { covariance-based structural equation (path) } \\
\text { modelling (SEM) and a } \\
\text { moderation approach }\end{array}$ & Management Accounting Research \\
\hline
\end{tabular}


Table A2

Bibliography of the selected articles relation to the MAPs of FBs to enhance their environmental performance

\begin{tabular}{|c|c|c|c|c|c|}
\hline Authors name & Published Years & $\begin{array}{l}\text { Research } \\
\text { Destination }\end{array}$ & $\begin{array}{l}\text { Research } \\
\text { method }\end{array}$ & Analytical tools used & Journal published \\
\hline Jenkins & 2004 & Mixed region & Quantitative & $\begin{array}{l}\text { Descriptive statistics, Exploratory factor } \\
\text { analysis }\end{array}$ & Journal of General management \\
\hline Hillary & 2004 & & Qualitative & A literature review & Journal of Cleaner Production \\
\hline $\begin{array}{l}\text { McKeiver and } \\
\text { Gadenne }\end{array}$ & 2005 & $\begin{array}{l}\text { Queensland, } \\
\text { Australia }\end{array}$ & Quantitative & $\begin{array}{l}\text { Descriptive statistics, Multivariate } \\
\text { analysis-of-variance (MANOVA) }\end{array}$ & International Small Business Journal \\
\hline Halila & 2007 & Swedish & Qualitative & Multi case studies & $\begin{array}{l}\text { Corporate Social Responsibility and } \\
\text { Environmental Management }\end{array}$ \\
\hline Nawrocka, & 2008 & Swedish & Qualitative & $\begin{array}{l}\text { Descriptive statistics, Exploratory factor } \\
\text { analysis }\end{array}$ & $\begin{array}{l}\text { Corporate Social Responsibility and } \\
\text { Environmental Management }\end{array}$ \\
\hline $\begin{array}{l}\text { Balzarova and } \\
\text { Castka, }\end{array}$ & 2008 & UK & Qualitative & A case study & $\begin{array}{l}\text { Journal of Cleaner } \\
\text { Production }\end{array}$ \\
\hline Heras and Arana & 2010 & $\begin{array}{l}\text { European union and } \\
\text { Japan }\end{array}$ & Qualitative & $\begin{array}{l}\text { Descriptive statistics, Exploratory factor } \\
\text { analysis }\end{array}$ & Journal of Cleaner Production \\
\hline Zorpas & 2010 & Cyprus & Qualitative & Exploratory factor analysis & Bioresource Technology \\
\hline $\begin{array}{l}\text { Stubblefield Loucks } \\
\text { et al. }\end{array}$ & 2010 & & Qualitative & A conceptual review & $\begin{array}{l}\text { Sustainability Accounting, } \\
\text { Management and Policy Journal }\end{array}$ \\
\hline Chan & 2011 & Hong Kong & Qualitative & $\begin{array}{l}\text { Descriptive statistics, Exploratory factor } \\
\text { analysis }\end{array}$ & $\begin{array}{l}\text { Journal of Hospitality and Tourism } \\
\text { Research }\end{array}$ \\
\hline Brammer et al. & 2012 & UK & Qualitative & $\begin{array}{l}\text { Descriptive statistics, Exploratory factor } \\
\text { analysis }\end{array}$ & Business Strategy and the Environment \\
\hline $\begin{array}{l}\text { Lavia Lopez and } \\
\text { Hiebl }\end{array}$ & $\begin{array}{l}\text { Lavia López and } \\
\text { Hiebl, } 2014\end{array}$ & & Qualitative & A systematic literature review & J. Management. Account. Research \\
\hline Ferenhof et al. & 2014 & & Qualitative & A literature review & Journal of Cleaner Production \\
\hline Granly and Welo & 2014 & Norwegian & Qualitative & Multi case study & Journal of Cleaner Production \\
\hline Singh et al. & 2015 & India & Quantitative & $\begin{array}{l}\text { Descriptive statistics, Multiple regression } \\
\text { analysis }\end{array}$ & Journal of Cleaner Production \\
\hline Horisch et al. & 2015 & Germany & Quantitative & $\begin{array}{l}\text { Descriptive statistics, Structural equation } \\
\text { model }\end{array}$ & Business Strategy and the Environment \\
\hline Santos et al. & 2016 & Portugal & Quantitative & Multivariate cluster analysis & Journal of Cleaner Production \\
\hline Graafland, J., Smid, & 2016 & Europe & Quantitative & $\begin{array}{l}\text { Descriptive statistics, Bivariate correlation } \\
\text { analysis }\end{array}$ & Journal of Cleaner Production \\
\hline $\begin{array}{l}\text { Johnson and } \\
\text { Schaltegger }\end{array}$ & 2016 & & Qualitative & A systematic literature review & Journal Small Business Management \\
\hline $\begin{array}{l}\text { Reyes-Rodríguez } \\
\text { et al. }\end{array}$ & 2016 & Danish & Quantitative & Descriptive statistics, Regression analysis & $\begin{array}{l}\text { Corporate Social Responsibility and } \\
\text { Environmental Management }\end{array}$ \\
\hline Witjes et al. & 2017 & Dutch SMEs & Qualitative & A cross-case study & Journal of Cleaner Production \\
\hline $\begin{array}{l}\text { Ferreira Rino and } \\
\text { Salvador }\end{array}$ & 2017 & Australia & Qualitative & $\begin{array}{l}\text { Descriptive statistics, } \\
\text { Exploratory factor analysis }\end{array}$ & Accounting, Auditing and Accountability \\
\hline Christine et al. & 2019 & Indonesia & Quantitative & Structural equation modelling & $\begin{array}{l}\text { International Journal of Energy Economics } \\
\text { and Policy }\end{array}$ \\
\hline Ghosh et al. & 2019 & & Qualitative & A systematic literature review & Journal Management Control \\
\hline Marcio et al. & 2020 & & Qualitative & A systematic literature review & Journal of Cleaner Production \\
\hline Mohamed and Jamil & 2020 & Malaysia & Quantitative & Structural equation modelling & $\begin{array}{l}\text { International Journal of Environment and } \\
\text { Sustainable Development }\end{array}$ \\
\hline
\end{tabular}

\section{References}

Abdel-Kader, M., Luther, R., 2006. Management accounting practices in the British food and drinks industry. Br. Food J. 108 (5), 336-357.

Aboelmaged, M., 2017. The drivers of sustainable manufacturing practices in Egyptian SMEs and their impact on competitive capabilities: a PLS-SEM model. J. Clean. Prod. 175, 207-221.

Acquaah, M., 2013. Management control systems, business strategy and performance: a comparative analysis of family and non-family businesses in a transition economy in Sub-Saharan Africa. Journal of Family Business Strategy 4 (2), 131-146.

Ahmad, K., 2012. The Use of Management Accounting Practices in Malaysian SMEs. PhD Thesis. published.

Alberto, Díaz de Junguitu, Erlantz, Allur, 2019. The Adoption of Environmental Management Systems Based on ISO 14001, EMAS, and Alternative Models for SMEs: A Qualitative Empirical Study. Sustainability, MDPI,. Open Access J. 11 (24), 1-17.

Ali, Sajid, Malo Alain, Alaa, Haque, Mohammad, 2015. Impact of activity based costing on firms' performance in Saudi. Arabia 27, 597-606.

Alonso-Paulí, E., Andre, F.J., 2015. Standardized environmental management systems as an internal management tool. Resour. Energy Econ. 40, 85-106.

Anderson, R.C., Reeb, D.M., 2004. Board composition: balancing family influence in SandP 500 firms. Adm. Sci. Q. 49 (2), 209-237.

Armas-Cruz, Yaiza, Gil-Soto, Esperanza, Oreja-Rodríguez, Juan R., 2017. Environmental management in SMEs: organizational and sectoral determinants in the context of an Outermost European Region. J. Bus. Econ. Manag. 18 (5), 935-953. https://doi.org/ 10.3846/16111699.2017.1373375.

Askarany, D., Yazdifar, H., Saeed, A., 2009. Supply chain management, activity-based costing and organisational factors. Int. J. Prod. Econ. 127, 238-248.

Audretsch, D.B., Hülsbeck, M., Lehmann, E.E., 2013. Families as active monitors of firm performance. Journal of Family Business Strategy 4 (2), 118-130.
Balzarova, M.A., Castka, P., 2008. Underlying mechanisms in the maintenance of ISO 14001 environmental management system. J. Clean. Prod. 16 (18), 1949-1957.

Becker, W., Ulrich, P., Staffel, M., 2011. Management accounting and controlling in German SMEs: do company size and family influence matter? Int. J. Entrepreneurial Ventur. 3 (3), 281-300.

Behery, Mohamed, Jabeen, Fauzia, Parakandi, Mohammed, 2014. Adopting a contemporary performance management system: a fast-growth small-to-medium enterprise (FGSME) in the UAE. Int. J. Prod. Perform. Manag. 63. https://doi.org/ 10.1108/IJPPM-07-2012-0076.

Bennett, M., James, P., 1997. Environment Related Management Accounting: Current Practice and Future Trends, 17. Greener Management International, Spring, pp. 33-51.

Berrone, P., Cruz, C., Gomez-Mejia, L.R., Larraza-Kintana, M., 2010. Socioemotional wealth and corporate responses to institutional pressures: do family-controlled firms pollute less? Adm. Sci. Q. 55 (1), 82-113.

Bingham, J.B., Dyer Jr., W.G., Smith, I., Adams, G.L., 2011. A stakeholder identity orientation approach to corporate social performance in family firms. J. Bus. Ethics 99 (4), 565-585.

Bisogno, Marco, Giovanni, Vaia, 2017. The role of management accounting in family business succession. Afr. J. Bus. Manag. 11 (21), 619-629. https://doi.org/10.5897/ AJBM2017.8396. NemNe.

Bloom, N., Van Reenen, J., 2007. Measuring and explaining management practices across firms and countries. Q. J. Econ. 122 (4), 1351-1408.

Brammer, Stephen, Hoejmose, Stefan, Marchant, Kerry, 2012. Environmental management in SMEs in the UK: practices, pressures and perceived benefits. Bus. Strat. Environ. 21, 423-434.

Burke, S., Gaughran, W.F., 2006. Intelligent environmental management for SMEs in manufacturing. Robot. Comput. Integr. Manuf. 22 (5), 566-575. 
Campopiano, G., De Massis, A., Chirico, F., 2014. Firm philanthropy in small-and medium-sized family firms: the effects of family involvement in ownership and management. Fam. Bus. Rev. 27 (3), 244-258.

Castka, Pavel, Prajogo, Daniel, 2013. The effect of pressure from secondary stakeholders on the internalization of ISO 14001. J. Clean. Prod. 47, 245-252. https://doi.org/ 10.1016/j.jclepro.2012.12.034.

Chan, E.S., 2011. Implementing environmental management systems in small-and medium-sized hotels: Obstacles. J. Hospit. Tourism Res. 35 (1), 3-23.

Chand, Mohinder, Dahiya, Ashish, 2010. Application of management accounting techniques in Indian small and medium hospitality enterprises: An empirical study. Int. J. Enterpren. Small Bus. 11 (1). https://doi.org/10.1504/IJESB.2010.034430.

Chenhall, R.H., 2003. 'Management Control Systems Design within its Organizational Context: Findings from Contingency-Based Research and Directions for the Future', Accounting, 28. Organizations and Society, pp. 127-168.

Chirico, F., Bau, M., 2014. Is the family an Asset or Liability for firm performance? The moderating role of environmental dynamism. J. Small Bus. Manag. 52 (2), 210-225.

Chrisman, J.J., Chua, J.H., Sharma, P., 2005. Trends and directions in the development of a strategic management theory of the family \$ rm. Enterpren. Theor. Pract. 29 (5), $555-576$.

Chrisman, J.J., Memili, E., Misra, K., 2014. Nonfamily managers, family firms, and the winner's curse: the influence of noneconomic goals and bounded rationality. Enterpren. Theor. Pract. 38 (5), 1103-1127.

CIMA, 2011. Sustainability and the role of the management accountant. Res. Exec. Summ. Ser. 7, 1-14.

Connelly, B.L., Tihanyi, L., Certo, S.T., Hitt, M.A., 2010. Marching to the beat of different drummers: the influence of institutional owners on competitive actions. Acad. Manag. J. 53 (4), 723-742.

Craig, Justin, Ken Moores, 2005. Balanced scorecards to drive the strategic planning of family firms family business review. (c) Family Firm Institute, Inc XVIII (2).

Cruz, C., Larraza-Kintana, M., Garcés-Galdeano, L., Berrone, P., 2014. Are family firms really more socially responsible? Enterpren. Theor. Pract. 38 (6), 1295-1316.

De Massis, A., Kotlar, J., Chua, J.H., Chrisman, J.J., 2014. Ability and willingness as sufficiency conditions for family-oriented particularistic behavior: implications for theory and empirical studies. J. Small Bus. Manag. 52 (2), 344-364.

Duller, C., 2010. Differences in management accounting between family enterprises and non-family enterprises: a statistical approach. Int. J. Econ. Sci. Appl. Res. 3 (1), 89-96.

Duller, C., Feldbauer-Durstmüller, B., Mitter, C., 2011. Corporate governance and management accounting in family firms: does generation matter? International Journal of Business Research 11 (1), 29-46.

Duréndez, Antonio, Madrid-Guijarro, Antonia, Garcia-Perez-de-Lema, Domingo, 2011. Innovative culture, management control systems and performance in small and medium-sized Spanish family firms. Innovar: Revista de Ciencias Administrativas y Sociales 21 (40), 137-154, 2011, págs. 137-154.

Dyer, W.G., Whetten, D.A., 2006. Family firms and social responsibility: preliminary evidence from the SandP 500. Enterpren. Theor. Pract. 30 (6), 785-802.

Efferin, S., Hartono, M.S., 2015. Management control and leadership styles in family business. J. Account. Organ. Change 11 (1), 130-159.

Epstein, M.J., Birchard, B., 1999. Measuring what Counts. Perseus Books, Reading.

European Commission, 2009. Final Report of Expert Group - Overview of FamilyBusiness-Related Issues: Research, Networks, Policy Measures and Existing Studies. Available online at: http://ec.europa.eu/enterprise/policies/sme/promoting-entrep reneurship/family-business/family_business_expert_group_report_en.pdf.

Feldbauer-Durstmüller, B., Duller, C., Greiling, D., 2012. Strategic management accounting in Austrian family firms. International Journal of Business Research 12 (1), 26-42.

Ferenhof, H.A., Vignochi, L., Selig, P.M., Lezana, A.G.R., Campos, L.M., 2014. Environmental management systems in small and medium-sized enterprises: an analysis and systematic review. J. Clean. Prod. 74, 44-53.

García-Pérez-de-Lema, D., Duréndez, A., 2007. Managerial behaviour of small and medium-sized family businesses: an empirical study. Int. J. Entrepreneurial Behav. Res. 13 (3), 151-172.

Garengo, P., Bititci, U., 2007. Towards a contingency approach to performance measurement: an empirical study in Scottish SMEs. Int. J. Oper. Prod. Manag. 27 (8), 802-825.

Giovannoni, E., Maraghini, M.P., Riccaboni, A., 2011. Transmitting knowledge across generations: the role of management accounting practices. Fam. Bus. Rev. 24 (2) 126-150.

Graafland, J., 2018. Does Corporate Social Responsibility Put Reputation at Risk by Inviting Activist Targeting? An Empirical Test among European SMEs. Corp. Soc. Responsib. Environ. Mgmt. 25 (1), 1-13. https://doi.org/10.1002/csr.1422.

Graafland, J., Smid, H., 2016. Environmental impacts of SMEs and the effects of formal management tools: evidence from EU's largest survey. Corp. Soc. Responsib. Environ. Manag. 23 (5), 297-307, 297-307.

Granly, B.M., Welo, T., 2014. EMS and sustainability: experiences with ISO 14001 and eco-lighthouse in Norwegian metal processing SMEs. J. Clean. Prod. 64, 194-204.

Groen, B.A.C., van de Belt, M., Wilderom, C.P.M., 2012. Enabling performance measurement in a small professional service firm. Int. J. Prod. Perform. Manag. 61 (8), 839-862.

Guenther, T.W., Heinicke, A., 2019. Relationships among types of use, levels of sophistication, and organizational outcomes of performance measurement systems: the crucial role of design choices. Manag. Account. Res. 42, 1-25.

Gunarathne, A.D.N., Lee, K.-H., Hitigala Kaluarachchilage, P.K., 2020. Institutional Pressures, Environmental Management Strategy, and Organizational Performance: the Role of Environmental Management Accounting. Bus Strat Env, pp. 1-15.
Halila, F., 2007. Networks as a means of supporting the adoption of organizational innovations in SMEs: the case of environmental management systems (EMSs) based on ISO 14001. Corp. Soc. Responsib. Environ. Manag. 14 (3), 167-181.

Hatum, A., Pettigrew, A., Michelini, J., 2010. Building organizational capabilities to adapt under turmoil. J. Change Manag. 10 (3), 257-274.

Heras, I., Arana, G., 2010. Alternative models for environmental management in SMEs: the case of ekoscan vs. ISO 14001. J. Clean. Prod. 18 (8), 726-735.

Heras-Saizarbitoria, I., Boiral, O., 2013. ISO 9001 and ISO 14001: towards a research agenda on management system standards. Int. J. Manag. Rev. 15 (1), 47-65. https:// doi.org/10.1111/j.1468-2370.2012.00334.x.

Hiebl, M.R.W., Duller, C., Feldbauer-Durstmüller, B., 2012. Do management accountants play a different role in family firms? Empirical evidence on management accountants' qualification and roles in family and non-family firms. International Journal of Business Research 12 (2), 94-103.

Hiebl, M.R.W., Feldbauer-Durstmüller, B., Duller, C., 2013. The changing role of management accounting in the transition from a family business to a non-family business. J. Account. Organ. Change 9 (2), 119-154.

Hillary, R., 2004. Environmental management systems and the smaller enterprise. J. Clean. Prod. 12 (6), 561-569.

Hopper, T., 1999. Postcard from Japan: a management accounting view. Account Audit. Account. J. 12 (1), 58-69. https://doi.org/10.1108/09513579910259924.

Hosoda, Masahiro., 2018. Management control systems and corporate social responsibility: Perspectives from a Japanese small company. Corp. Govern.: Int. J. Bus. Soc. 18 (1), 68-80. https://doi.org/10.1108/CG-05-2017-0105.

Huerta, E., Petrides, Y., O'Shaughnessy, D., 2017. Introduction of accounting practices in small family businesses. Qual. Res. Account. Manag. 14 (2), 111-136.

Imoniana, O.J., Perera, J.L.C., Lima, G.F., Antunes, P.M.T., 2011. The dialectic of control culture in SMEs: a case study. Int. J. Bus. Strat. 11 (2), 39-48.

Jamali, D., 2010. The CSR of MNC subsidiaries in developing countries: Global, local, substantive or diluted. J. Bus. Ethics 93, 181-200.

Jenkins, H., 2004. A Critique of Conventional CSR theory: an SME perspective. J. Gen. Manag. 29 (4), 37-57.

Johnson, M.P., Schaltegger, S., 2016. Two decades of sustainability management tools for SMEs: how far have we come? J. Small Bus. Manag. 54 (2), 481-505.

Jorissen, A., Laveren, E., Martens, R., Reheul, A.-M., 2005. Real versus sample-based. Journal of Family Business Strategy 3 (1), 28-37.

Kaplan, R., Atkinson, A., 1998. Advanced Management Accounting, third ed. Pearson.

Kidwell, R.E., Kellermanns, F.W., Eddleston, K.A., 2012. Harmony, justice, confusion, and conflict in family firms: implications for ethical climate and the fredo effect. J. Bus. Ethics 106 (4), 503-517.

Kim, J., Fairclough, S., Dibrell, C., 2016. Attention, Action, and Greenwash in Family Influenced Firms? Evidence from Polluting Industries. Organization and Environment, pp. 1-20.

Kotey, B., 2005. Are performance differences between family and non-family SMEs uniform across all firm sizes? Int. J. Entrepreneurial Behav. Res. 11 (6), 394-421.

Laitinen, E.K., 2008. Value drivers in Finnish family-owned firms: profitability, growth and risk. Int. J. Account. Finance 1 (1), 1-41.

Lavia López, O., Hiebl, M.R., 2014. Management accounting in small and medium sized enterprises: current knowledge and avenues for further research. J. Manag. Account. Res. 27 (1), 81-119.

Le Breton-Miller, I., Miller, D., 2016. Family firms and practices of sustainability: a contingency view. Journal of Family Business Strategy 7 (1), 26-33.

Leenders, M., Waarts, E., 2003. Competitiveness and evolution of family businesses: the role of family and business orientation. Eur. Manag. J. 21 (6), 686-697.

Leotta, A., Rizza, C., Ruggeri, D., 2017. Management accounting and leadership construction in family firms. Qual. Res. Account. Manag. 14 (2), 189-207.

Lepoutre, Jan, Heene, Aimé, 2006. Investigating the Impact of Firm Size on Small Business Social Responsibility: A Critical Review. J. Business Ethics 673, 257-273.

Marriott, N., Marriott, P., 2000. Professional accountants and the development of a management accounting service for the small firm: barriers and possibilities. Manag. Account. Res. 11 (4), 475-492.

Mayr, S., 2012. Management accounting in Eastern Europe: cultural influence and empirical evidence from Slovakia. International Journal of Business Research 12 (3), 161-169.

McKeiver, C., Gadenne, D., 2005. Environmental management systems in small and medium businesses. Int. Small Bus. J. 23 (5), 513-537.

Mitter, C., Hiebl, M.R., 2017. The role of management accounting in international entrepreneurship. J. Account. Organ. Change 13 (3), 381-409.

Mohamed, R, Jamil, C.Z.M., 2020. The influence of environmental management accounting practices on environmental performance in small-medium manufacturing in Malaysia. Int. J. Environ. Sustain Dev. 19 (4), 378392.

Moilanen, S., 2008. The role of accounting in the management control system: a case study of a family-led firm. Qual. Res. Account. Manag. 5 (3), 165-183.

Moores, K., Yuen, S., 2001. Management accounting systems and organizational configuration: a life-cycle perspective. Account. Org. Soc. 26 (4/5), 351-389.

Nawrocka, D., 2008. Environmental supply chain management, ISO 14001 and RoHS. How are small companies in the electronics sector managing? Corp. Soc. Responsib. Environ. Manag. 15 (6), 349-360.

Németh, K., Németh, S., 2017. The Application and Role of Management Accounting and Controlling Methods in Family Businesses - Experiences of an Empirical Survey. In: Management Challenges in a Network Economy: Proceedings of the MakeLearn and TIIM International Conference 2017.

Neubauer, H., Mayr, S., Feldbauer-Durstmüller, B., Duller, C., 2012. Management accounting systems and institutionalization in medium-sized and large family businesses - empirical evidence from Germany and Austria. European Journal of Management 12 (2), 14-69. 
Prencipe, Annalisa, Bar-Yosef, Sasson, Dekker, Henri, Prencipe, Annalisa \& Bar-Yosef, Sasson \& Dekker, Henri., 2014. Accounting research in family firms: theoretical and empirical challenges. Eur. Account. Rev. 23 (3), 361-385.

Reay, T., Berta, W., Kohn, M.K., 2009. What's the evidence on evidence-based management? Acad. Manag. Perspect. 23 (4), 5-18.

Reyes-Rodríguez, J., Ulhøi, J., Madsen, H., 2014. Corporate Environmental Sustainability in Danish SMEs: A Longitudinal Study of Motivators, Initiatives, and Strategic Effects, 23. Corporate Social Responsibility and Environmental Management.

Carlos Alberto Ferreira, Rino, Salvador, N.N.B., 2017. ISO 14001 certification process and reduction of environmental penalties in organizations in Sao Paulo State, Brazil. J. Clean. Prod. 142, 3627-3633.

Salvato, C, Moores, K, 2010. Research on Accounting in Family Firms: Past Accomplishments and Future Challenges. Fam. Bus. Rev. 23 (3), 193-215. https:// doi.org/10.1177/0894486510375069.

Santos, G., Rebelo, M., Lopes, N., Alves, M.R., Silva, R., 2016. Implementing and certifying ISO 14001 in Portugal: motives, difficulties and benefits after ISO 9001 certification. Total Qual. Manag. Bus. Excel. 27, 1211-1223.

Scapens, R.W., 1994. Never mind the gap: towards an institutional perspective on management accounting practice. Manag. Account. Res. 5 (3-4), 301-321.

Schaltegger, R., Burritt, L., 2010. Sustainability accounting for companies: catchphrase or decision support for business leaders? J. World Bus. 45, 375-384.

Schulze, W.S., Lubatkin, M.H., Dino, R.N., Buchholz, A.K., 2001. Agency relationships in family firms: Theory and evidence. Organization Science 12 (2), 99-116.

Senftlechner, D., Hiebl, M.R.W., 2015. Management accounting and management control in family businesses: Past accomplishments and future opportunities. J. Account. Organ. Change 11 (4), 573-606.

Sharma, P., Sharma, S., 2011. Drivers of proactive environmental strategy in family firms. Bus. Ethics Q. 21, 309-334, 02.

Singh, M., Brueckner, M., Padhy, P.K., 2015. Environmental management system ISO 14001: effective waste minimisation in small and medium enterprises in India. J. Clean. Prod. 102, 285-301.

Songini, Lucrezia, Gnan, Luca, Malmi, Teemu, 2013. The role and impact of accounting in family business. J. Fam. Bus. Strat. 4 (2), 71-83. https://doi.org/10.1016/ j.jfbs.2013.04.002.

Speckbacher, G., Wentges, P., 2012. The impact of family control on the use of performance measures in strategic target setting and incentive compensation: a research note. Manag. Account. Res. 23 (1), 34-46.

Stergiou, K., Ashraf, J., Uddin, S., 2013. The role of structure and agency in management accounting control change of a family owned firm: a Greek case study. Crit. Perspect. Account. 24 (1), 62-73.
Stubblefield Loucks, E., Martens, M.L., Cho, C.H., 2010. Engaging small-and medium sized businesses in sustainability. Sustainabil. Acc. Manag. Policy J. 1 (2), 178-200.

Thomas, G, Anja, H, 2019. Relationships among types of use, levels of sophistication, and organizational outcomes of performance measurement systems: The crucial role of design choices. Manag. Account. Res. 42, 125. https://doi.org/10.1016/ j.mar.2018.07.002.

Tranfield, D., Denyer, D., Smart, P., 2003. Towards a methodology for developing evidence-informed management knowledge by means of systematic review. Br. J. Manag. 14 (3), 207-222.

Tsamenyi, M., Noormansyah, I., Uddin, S., 2008. Management controls in family-owned businesses (FOBs): a case study of an Indonesian family-owned University. Account. Forum 32 (1), 62-74.

Tsui-Auch, L.S., 2003. Learning strategies of small and medium-sized Chinese family firms: a comparative study of two suppliers in Singapore. Manag. Learn. 34 (2), 201-220.

Uddin, S., 2009. Rationalities, domination and accounting control: a case study from a traditional society. Crit. Perspect. Account. 20 (6), 782-794.

Ungerer, Marius, Mienie, Carel, 2018. A family business success map to enhance the sustainability of a multi-generational family business. International Journal of Family Business and Management 2, 10.

Voukkali, I., Loizia, P., Pociovalisteanu, D.M., Zorpas, A.A., 2017. Barriers and difficulties concerning the implementation of an environmental management system in a bakeryconfectionary industry in Cyprus for 8 years. Environ. Process. 4 (1), 263-275.

Witjes, S., Vermeulen, W.J., Cramer, J.M., 2017. Exploring corporate sustainability integration into business activities. Experiences from 18 small and medium sized enterprises in The Netherlands. J. Clean. Prod. 153, 528-538.

Yong, J.Y., Yusliza, M.-Y., Ramayah, T., Chiappetta Jabbour, C.J., Sehnem, S., Venkatesh, M., 2020. Pathways towards sustainability in manufacturing organizations: empirical evidence on the role of green human resource management. Bus. Strat. Environ. 29, 212-228.

Youssef, M.A., 2013. Management accounting change in an Egyptian organization: an institutional analysis. J. Account. Organ. Change 9 (1), 50-73.

Zobel, T., 2007. The'pros'and'cons'of joint EMS and group certification: a Swedish case study.Corporate Social Responsibility and. Environ. Manag. 14 (3), 152-166. https:// doi.org/10.1002/csr.125.

Zorpas, A., 2010. Environmental management systems as sustainable tools in the way of life for the SMEs and VSMEs. Bioresour. Technol. 101 (6), 1544-1557. 